Article

\title{
First Report of Small Shelly Fossils from the Cambrian Miaolingian Limestones (Zhangxia and Hsuzhuang Formations) in Yiyang County, Henan Province of North China
}

\author{
Yazhou Hu ${ }^{1}\left(\mathbb{D}\right.$, Lars E. Holmer ${ }^{1,2} \mathbb{D}$, Yue Liang ${ }^{1,2}$, Xiaolin Duan ${ }^{1}$ and Zhifei Zhang ${ }^{1, *(\mathbb{D})}$ \\ 1 State Key Laboratory of Continental Dynamics, Shaanxi Key Laboratory of Early Life \& Environments, \\ Department of Geology, Northwest University, Xi'an 710069, China; huyz_nwu@163.com (Y.H.); \\ lars.holmer@pal.uu.se (L.E.H.); yueliang_nwu@outlook.com (Y.L.); duan_nwu@163.com (X.D.) \\ 2 Department of Earth Sciences, Palaeobiology, Uppsala University, SE-752 36 Uppsala, Sweden \\ * Correspondence: elizf@nwu.edu.cn
}

Citation: Hu, Y.; Holmer, L.E.; Liang, Y.; Duan, X.; Zhang, Z. First Report of Small Shelly Fossils from the Cambrian Miaolingian Limestones (Zhangxia and Hsuzhuang Formations) in Yiyang County, Henan Province of North China. Minerals 2021, 11, 1104. https://doi.org/ $10.3390 / \min 11101104$

Academic Editors: Francisco

J. González, Oluwatoosin Agbaje and Olev Vinn

Received: 9 September 2021

Accepted: 1 October 2021

Published: 9 October 2021

Publisher's Note: MDPI stays neutral with regard to jurisdictional claims in published maps and institutional affiliations.

Copyright: (c) 2021 by the authors. Licensee MDPI, Basel, Switzerland. This article is an open access article distributed under the terms and conditions of the Creative Commons Attribution (CC BY) license (https:// creativecommons.org/licenses/by/ $4.0 /)$

\begin{abstract}
Small Shelly Fossils (SSFs) from the Cambrian are widely distributed and well known across different paleocontinents of the world. However, middle Cambrian SSFs from North China Platform have only rarely been documented until now. In this paper, we presented the first report on SSFs from bioclastic and oolitic limestones of the Zhangxia and Hsuzhuang formations of Henan province, North China. The carbonate-hosted fauna includes brachiopods (Micromitra sp., M. modesta, Eoobolus sp., and Schizopholis sp.), helcionellids (Oelandiella accordionata and O. aliciae), hyolithids, Hyolithellus sp., Chancelloria eros, sponge spicules, echinoderm ossicles, and chancelloriid sclerites. In terms of preservation, the brachiopod shell valves of M. modesta appeared to be homogeneous, consisting of tightly packed phosphate grains. Eoobolus sp. is composed of primary layer and secondary baculate, both of which consist of tightly compacted phosphate grains. Schizopholis sp. has multiple-lamellar phosphatized microstructures that distinctly differ from the other brachiopods recovered from the Longwanggou section. A similar multiple-lamellar microstructure was also revealed in conchs of Hyolithellus, with tightly compacted phosphate grains. The argillaceous shell of Oelandiella accordionata and O. aliciae, and the calcitic inner molds of hyolith did not preserve any shell structure. The helcionellids O. accordionata and O. aliciae and the brachiopod M. modesta were reported for the first time from North China. The fauna is most similar to the middle Cambrian faunas of Australia, in the brachiopod and mollusk components; it is also similar in composition of brachiopods and mollusks to coeval faunas from South China. The new fauna of SSFs in the Yiyang Longwanggou Section indicated that the Hsuzhuang and Zhangxia formations are late Drumian to middle Guzhuangian in age, most likely correlating with the Murrawong Creek Formation of Australia.
\end{abstract}

Keywords: small shelly fauna; middle Cambrian; Zhangxia Formation; Hsuzhuang Formation; North China

\section{Introduction}

Diverse kinds of data are needed for characterizing and global correlation of stratigraphic intervals in the Cambrian across the paleocontinents. The most abundant and diverse biostratigraphic data in early to middle Cambrian successions come from Small Shelly Fossils (SSFs), which are well documented and broadly known from the lower Cambrian of South China [1,2] and North China (Figure 1). In recent years, SSFs from the Xinji Formation have been studied in detail. Among the SSFs, hyoliths and mollusks have a high diversity and disparity and are the typical representatives of SSFs from North China Platform (NCP) [3-7]. Brachiopods, though less abundant, have also been reported recently by Pan et al. from the basal Cambrian of North China [8], in connection with studies of the Shuiyu Section, Shanxi Province. 
In the lower Cambrian of China, the celebrated Burgess Shale Type Lagerstätten are widely distributed [9], yielding the Qingjiang biota [10], Chengjiang biota [11], Guanshan biota [9,12-14], Balang biota, and Shipai biota [15-18], all of which are exclusively located in South China. Owing to large amounts of field excavations, the Burgess Shale Type fossil components and related faunal assemblages from North China were recently recovered from the Zhangxia Formation and Hsuzhuang Formation of Shandong province [19-23]. Recently, Liu et al. illustrated some well-preserved shell valves of brachiopods from the upper part of the Hsuzhuang Formation [22]. These studies, mentioned above, have made Miaolingian deposits (represented by the siliciclastic sediment intercalated with carbonates of Zhangxia and Hsuzhuang formations) some of the most intensively investigated in North China. In contrast to the highly diverse SSFs from the lowermost Cambrian Xiji Formation, there is a serious dearth of general reports on SSFs etched from Zhangxia and Hsuzhuang formations; however, there are a few papers dealing with acid-etched monotaxic materials, i.e., the acrotretids [24], and the skeletal build-ups by some fossils affiliated with Cnidaria [25]. Here, we presented the first study of a diverse and abundant assemblage of SSFs from the Zhangxia and Hsuzhuang formations, Miaolingian, from the Longwanggou Section, Yiyang County, Henan Province of Central China, ca. $180 \mathrm{~km}$ southeast of the Shuiyu section of Shanxi province (Figure 1A,B). The new assemblage comprises helcionellids, linguloids, paterinids, chancelloriids, hyoliths, and other skeletal components. The fossils showed well-preserved shell or skeletal textures and ornamentation.

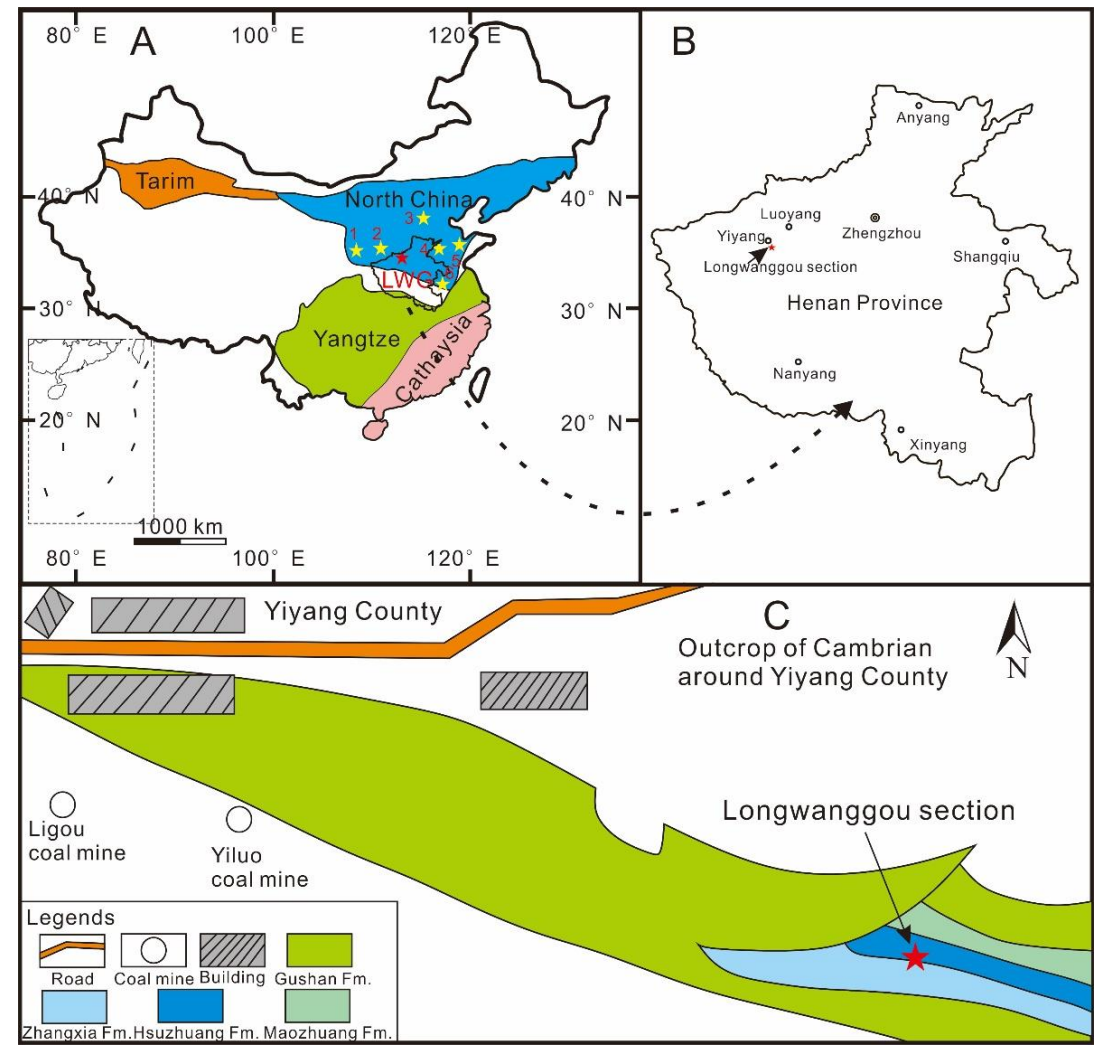

Figure 1. Simplified geological map of China, sketchy geographical map of Henan Province, and the Cambrian outcrops in Yiyang County, showing the location of the Longwanggou section studied herein. (A) Sketchy and simplified geographical and geological map showing the distribution of North China and South China platforms in China; note the fossil localities investigated earlier (yellow stars) and in this paper (red star). (B) Sketch map of the Henan Province, indicating the location of Longwanggou section in the Henan Province. (C) Cambrian outcrops around Yiyang County with stratigraphic sequences comprising Maozhuang, Hsuzhuang, Zhangxia, and Gushan formations; The Longwanggou section is labelled by a red star. Abbreviation: 1 = Chaijiawa section in Yun et al. [26], 2 = Shuiyu section in Pan et al. [8], 3 = Qingxing section in Mei [24], 4 = Mantoushan section in Park et al. [25], 5 = Weifang section in Liu et al. [22], $6=$ Xiaomeiyao section in Pan et al. [27]. 


\section{Geological Background}

The Cambrian outcrops occur extensively along the southern margin of NCP from western Shaanxi in the west, through southern Shanxi and Henan provinces in the middle to Shandong province in the east (Figure 1A). The traditional "Lower" and "Middle" Cambrian chronostratigraphic units officially adopted in North China have been established at stratotype sections mainly located in Jinan City of Shandong province; in ascending order, these are the Mantou, Maozhuang, Hsuzhuang, and Zhangxia formations. In both North China and South China, marine sequences are known in the Henan Province, providing an ideal opportunity to compare the contemporaneous faunal composition. In the Yiyang area, North China type Precambrian-Paleozoic deposits are well exposed and developed in considerable thickness. The well-exposed stratigraphic sequence makes the Yiyang area attractive for new investigations, and they have long been studied by researchers and students from universities around and within the Henan Province.

Longwanggou is one of the type sections that exemplifies the Paleozoic sequences from the lower Cambrian upward to Permian, with the upper part of the Cambrian (Figure 1C), Silurian, Devonian, and most Carboniferous deposits missing. Six formations of the Cambrian have been established in ascending order-the Zhushadong, Mantou, Maozhuang, Hsuzhuang, Zhangxia, and Gushan formations. The well-developed and well-exposed Hsuzhuang Formation is dominated by limestone, bioclastic limestone, and greenish and red mudstone (Figure 2A), conformably overlain by the thick-bedded massive limestone of Zhangxia Formation, and underlaid by brownish-reddish siltstone and the mudstonecontrolled Maozhuang Formation (Figure 2B-D). The Zhangxia Formation consists of oolitic limestone, bioclastic limestone, and marlstone, unambiguously differentiated from the underlaid Hsuzhuang formation that is characterized by brownish-reddish siltstone and mudstone intercalated by laminated and fossiliferous limestones (Figure 2B-D).
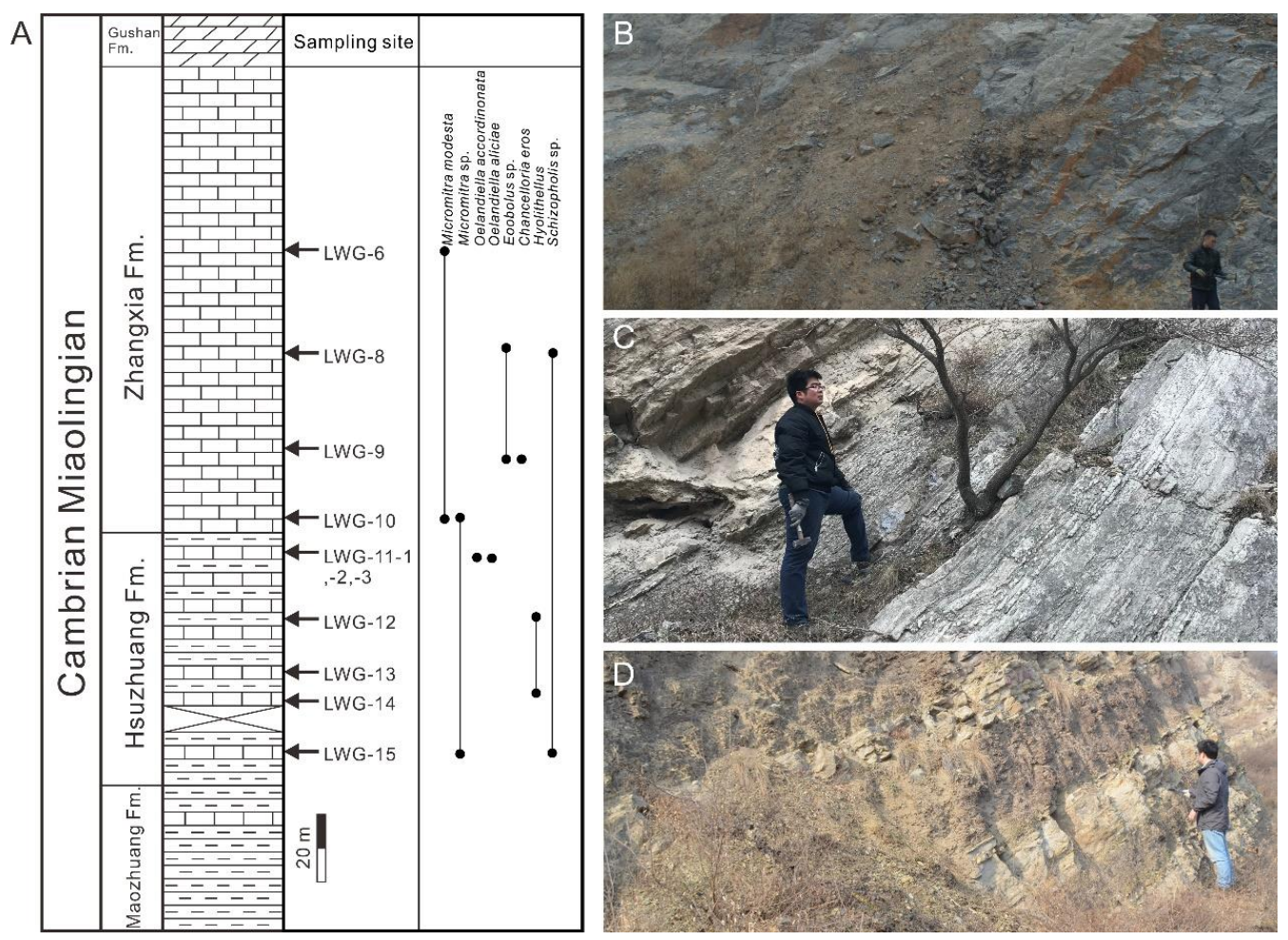

Figure 2. Stratigraphic column of the Zhangxia and Hsuzhuang formations and the field outcrop photographs. (A) Stratigraphic column of the Zhangxia and Hsuzhuang formations at Longwanggou Section to show the horizontal levels of samples collected for acid-maceration. (B-D) Field photographs of the Longwanggou section. (B) Showing the thick-bedded oolitic limestone of the Zhangxia Formation; (C) The thin-bedded limestone of the lower most of the Zhangxia Formation; (D) The limestone interbedded with mudstone of the Hsuzhuang Formation. 


\section{Methods and Material}

The well-exposed outcrops of the Zhangxia and Hsuzhuang formations at the Longwanggou section contain mostly fossiliferous samples. The Hsuzhuang Formation is composed of a ca. 100 m-thick green shale and limestone, containing skeletal fossils in the limestone, interbedded with shale (samples LWG-11 to LWG-15) (Figure 2B-D). Acetic acid maceration of the bioclastic limestone and oolitic limestone in the Zhangxia Formation (samples LWG-6 to LWG 10 in Figure 2A) revealed an assortment of abundant skeletal fossils with abundant skeletal and shelly individuals in the level of sample LWG-6, LWG-8, and LWG-9 (Figure 2A). Phosphatized tubular fossils and brachiopods, calcitic inner-mold, and argillaceous shell were extracted from buffered acetic acid (5\%-10\%) at the Early Life Institute, Northwest University, Xi'an. SSFs were picked out manually using a ZEISS Stemi 305 microscope at the Early Life Institute, Northwest University, Xi'an, China from the scattered insoluble residues. Most recovered phosphatized tubular fossils, calcitic internal molds, and phosphatic brachiopods are fragile and grayish or grayish-white in color. Small brachiopod fragments and calcitic internal molds of hyoliths predominate. In spite of the predominance of scattered-shell fragments, some complete individuals of brachiopods were found, some with exquisite preservation of the shell structures and micro-ornaments of the phosphatized shell, which allow identification. The articulated brachiopods were not studied. The interpretation of the SSFs similarities was facilitated by multivariate cluster analysis (based on Jaccard similarity) using the computer program PAST (Version 3.06) [28]. Then, those SSFs were placed on copper plate, gold coated, and were photographed using the Scanning Electron Microscopy facilities at the State Key Laboratory of Continental Dynamics, Northwest University.

\section{Previous Paleontological Work on the Zhangxia and Hsuzhuang Formations of Henan Province}

Works on the middle Cambrian of the Henan Province were mainly carried out during the 1960s. The first comprehensive investigation of the paleontology and biostratigraphy of the Henan Province was carried out in the 1990s by the Henan Provincial Bureau of Geology and Mineral Resources and summarized by Pei [29,30]. They described the trilobite fauna from the Zhangxia and Hsuzhuang formations. The Hsuzhuang Formation at the Northwestern Henan Province (e.g., Weihui, Linzhou and Mianchi County) ordinarily contains rich and index fossils of the trilobite Hsuzhuangia, despite the uppermost part yielding the trilobite genera of Bailiella and Lioparia. Three trilobite biozones were identified in the Zhangxia Formation, encompassing the Crepicephalina, Plebiellus, and Tailznia-Poshani trilobite zones (in ascending order) based on the fossil assemblages investigated in Weihui County [29]. However, there were no subsequent studies of brachiopods and other faunas from all of the Henan Province except for the report of sponge by Liu et al. [31]. As mentioned before, the studies of SSFs from NCP are from the Xinji, Suyukou, and Houjiashan formations, lower Cambrian. Nevertheless, the Cambrian trilobite assemblages or biozones in the Longwanggou section and even in the entire Yiyang area remain poorly known at the present time.

\section{Fossil Assemblage from the Zhangxia and Hsuzhuang Formations at the Longwanggou Section and Global Correlations}

\subsection{Fossil Assemblages}

In terms of total species richness, the Zhangxia and Hsuzhuang formations had a comparatively low diversity compared with SSFs from the Xinji Formation, lower Cambrian, NCP $[3-5,7,8,26,27,32-35]$. This may be due to the restricted taphonomic conditions preventing the preservation of SSFs in the middle Cambrian of North China. Brachiopods and hyoliths were the most abundant components in the fauna, but with them occurred several other skeletal remains. Hyoliths were the most abundant forms (Figure 3A-D; $n \geq 2273$ ), largely collected by means of acid-etching technique. Most of them were calcitic inner mold with no ornament and structure. Mollusks (Oelandiella accordionata and O. aliciae, 
see Section 6 for details) (Figure $4 ; n \geq 13$ ), Chancelloriidae (e.g., Chancelloria eros) (Figure 5; $n=20$ ), echinoderm ossicles (Figure 3E1,E2; $n=3$ ), and sponge spicules (Figure 3F; $n=1$ ) were less abundant. In addition, fragments of ptychopterid trilobites (Figure 3G,H; $n=177$ ) as well as Hyolithellus-like tubular fossils (Figure $6 ; n=129$ ) were also found.

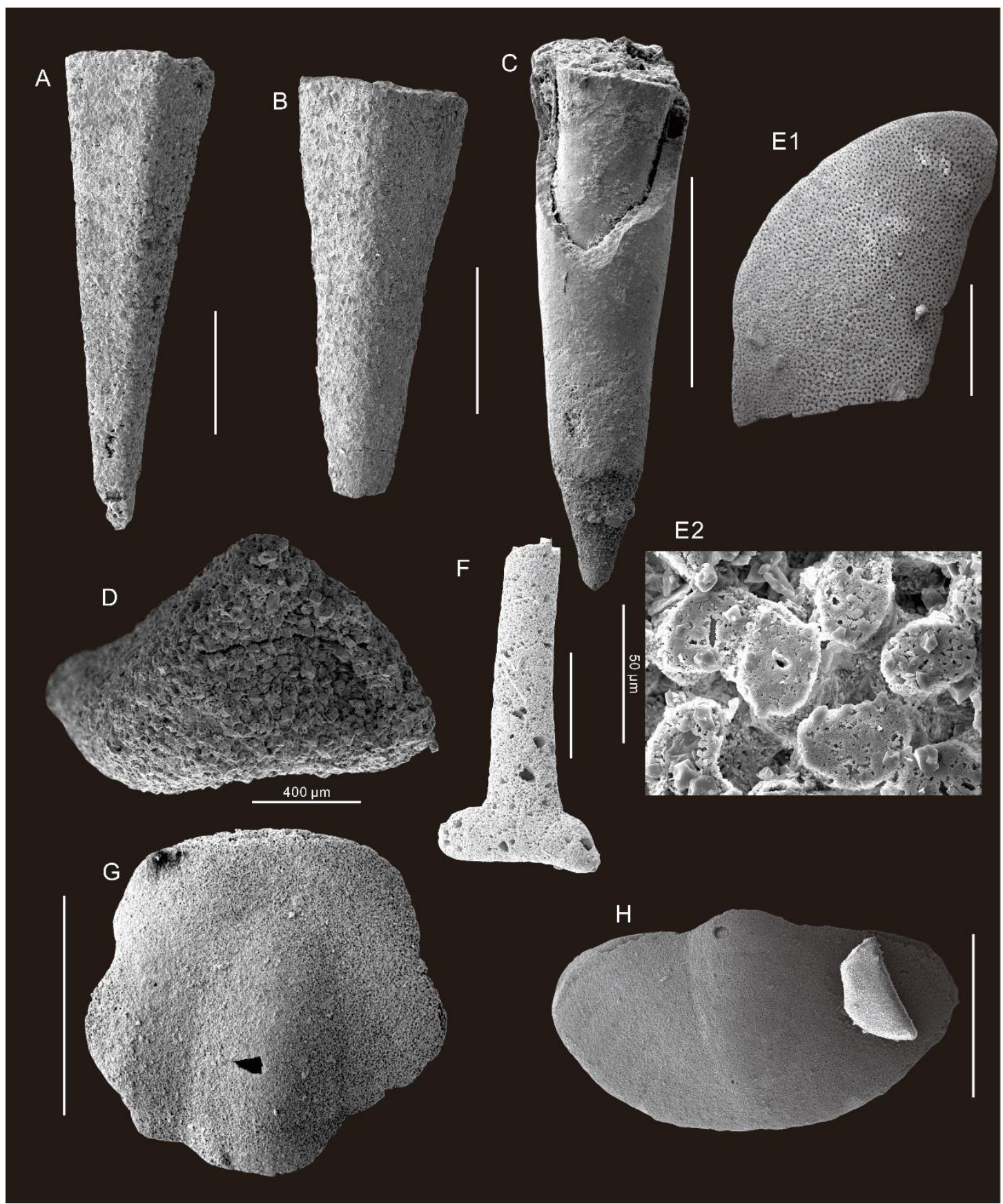

Figure 3. Skeletal fossils comprising hyolithids, echinoderms, sponge spicules, and ptychopariida trilobite, macerated from the Zhangxia and Hsuzhuang formations. (A,B) Internal molds of hyolithid from the Zhangxia Formation. (C) ELI-LWG-12002, a hyolithid conch infilled with sediment from the Hsuzhuang Formation. (D) Cross section of the internal molds of hyolithid from the Zhangxia Formation. (E1,E2) ELI-LWG-14-001, general and close-up views of an echinoderm ossicles with the microstructure (E2). (F) ELI-LWG-15-001, a sponge spicule from the Hsuzhuang Formation. (G,H) ELI-LWG-11-1-001, ELI-LWG-11-3-008, trilobite exoskeletons (ptychopariida) from the Hsuzhuang Formation. All scale bar = $1 \mathrm{~mm}$, except for those labeled. 


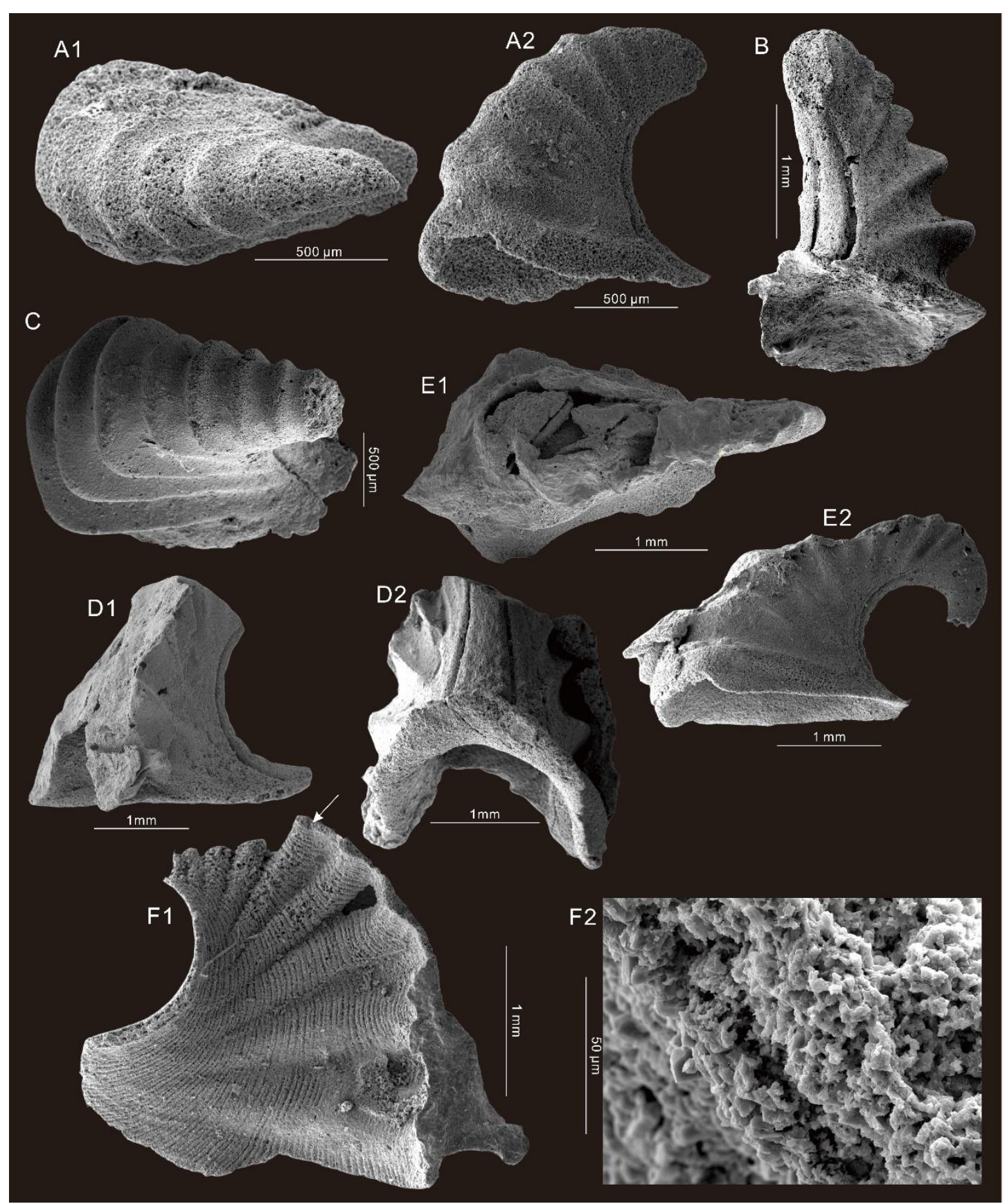

Figure 4. Helcionellid from the Hsuzhuang Formation, at Longwanggou section, Henan Province, North China. (A-D) Oelandiella accordinonata. (A1) Dorsal and posterior views with angular commarginal rugae crossing the whole ridge of the shell. (A2) Lateral view (ELI-LWG-11-3-003). (B) Ventral view showing a pair of uniformly thin ridges on the sub-apical shell wall (ELI-LWG-11-3-007). (C) Dorsal and lateral views, showing angular commarginal rugae crossing the whole ridge of the shell (ELI-LWG-11-3-001). (D1) Lateral view (ELI-LWG-11-3-002). (D2) Ventral view showing a pair of uniformly thin ridges on the sub-apical shell wall. (E1,E2) Oelandiella aliciae (ELI-LWG-11-3-005). (E1) Dorsal view, with angular commarginal rugae crossing the whole ridge of the shell, shell locally broken. (E2) Lateral view of the thin ridges on the sub-apical shell wall. (F1,F2) ELI-LWG-11-3-007 Shell fragment, possibly replaced by clay minerals. (F1) Interior mold, with fine radial ornamentation. (F2) Enlarged area in F1 pointed by arrow, showing the microstructure.

Four species of brachiopod taxa are described (see Section 6 for details), two of them belonging to the Class Paterinata, the rest two belonging to the Class Lingulida of the subphylum Linguliformea [36]. Paterinids are the most abundant, and are here referred to as Micromitra, i.e., M. modesta Lochman, 1940 (Figures 7 and $8 ; n \geq 78$ ). The rest of the 
brachiopod fauna included two species, comprising Eoobolus sp. (Figure 9; $n=565$ ) and Schizopholis sp. (Figure 10; $n=6$ ). Most of the brachiopod shell valves were represented by disarticulated and broken fragments and conjoined shells were lacking.

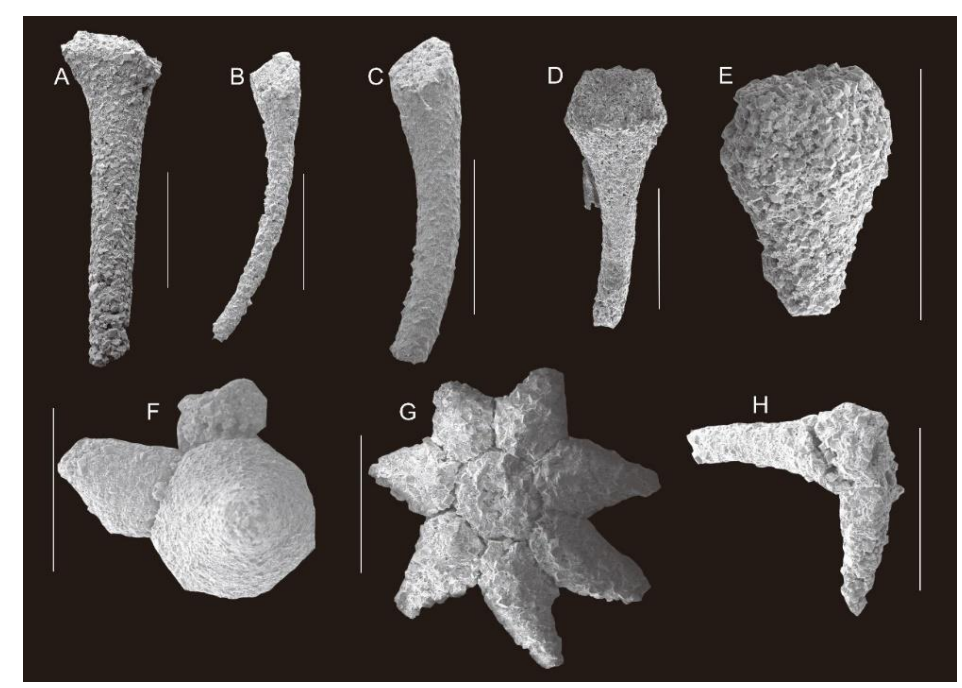

Figure 5. Chancelloriidae sclerites recovered from the Zhangxia Formation, Yiyang County, Henan Province, North China, all specimens preserved as calcite inner mold. (A-C) Lateral rays (ELI-LWG-9A0016, ELI-LWG-9A-0013, ELI-LWG-9A-0018). (D,E) Central rays (ELI-LWG-9A-008, ELI-LWG-9A-0015). (F,G) $7+1$ chancelloriidae sclerites of Chancelloria eros (ELI-LWG-9A-0010, ELI-LWG-9A-0011). (H) An incomplete chancelloriidae sclerite, possibly $4+1$ sclerite (ELI-LWG-9A-0012). Scale bar equal to $1 \mathrm{~mm}$.

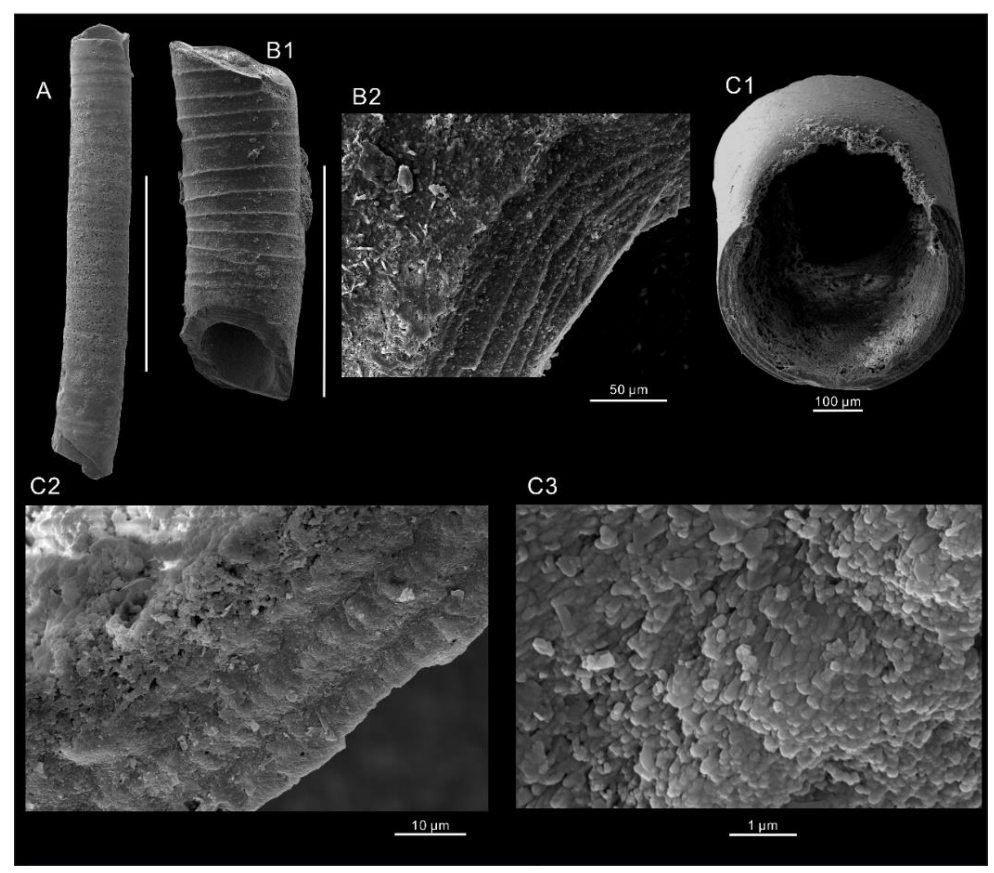

Figure 6. Hyolithellus sp. from the Hsuzhuang Formation at the Longwanggou section, Yiyang County, Henan Province, North China. (A) ELI-LWG-13-002, Hyolithellus sp. from the Hsuzhuang Formation occurring with annulate ornamentations. (B1) ELI-LWG-12-005, Hyolithellus sp. from the Hsuzhuang Formation, occurring with annulated ornamentations. (B2) Showing the multiple layer structures. (C1) ELI-LWG-12-0011, Hyolithellus sp. from the Hsuzhuang Formation, showing the multiple lamellar layer structures. (C2,C3) Enlargement of the lamellar layers, with tightly compacted and well oriented phosphate grains. Scale bar equal to $1 \mathrm{~mm}$, except for those labelled. 


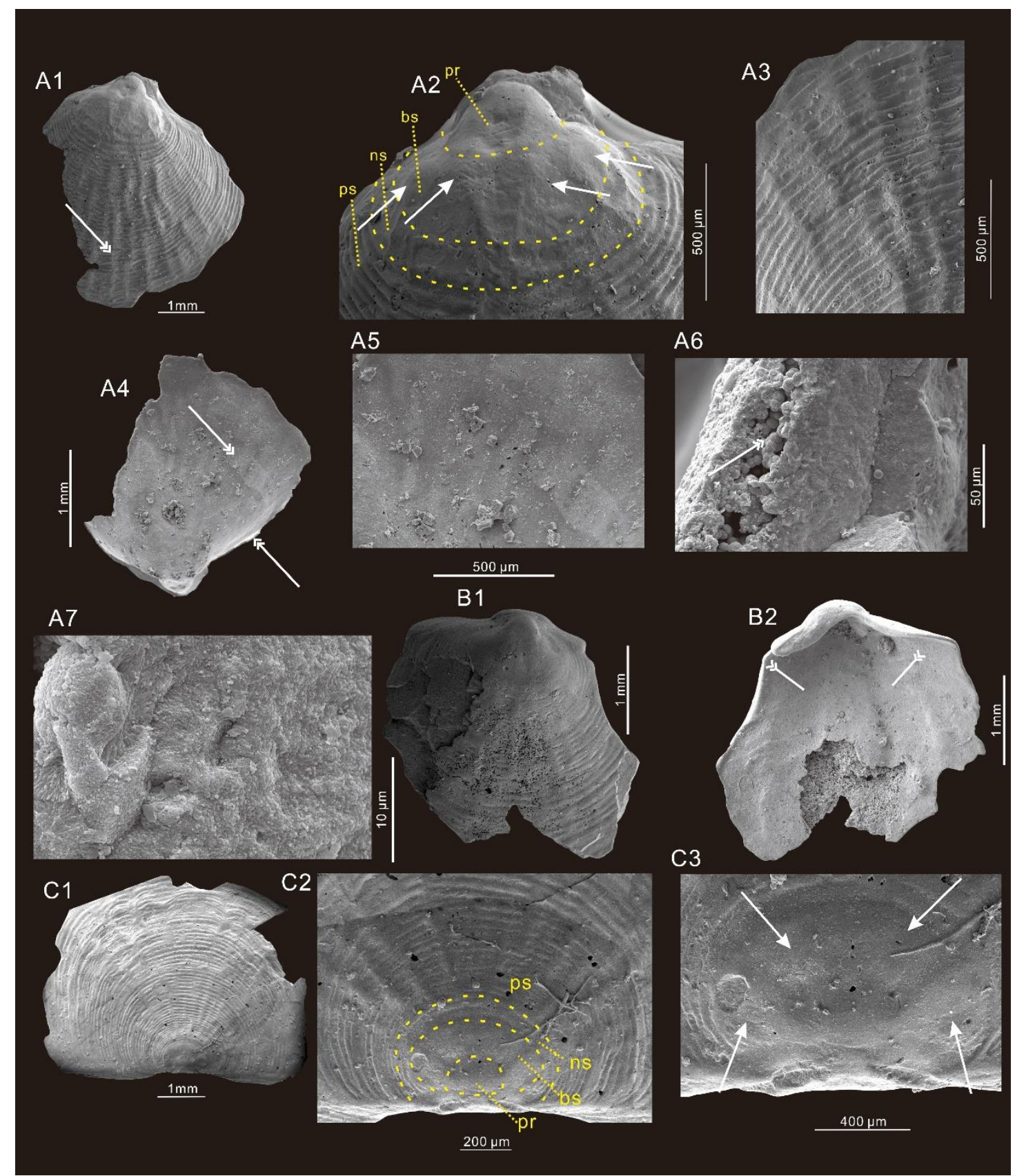

Figure 7. Micromitra modesta from the Zhangxia Formation at the Longwanggou section, Yiyang County, Henan Province. (A1) ELI-LWG-6-0012, ventral valve. (A2) Posterolateral view of ventral view showing the metamorphic shell including the protegulum, brephic, and neanic shell, white arrows showing two pairs of lobes flanking. (A3) Exterior view, showing the radial ornamentations. (A4) Interior view. (A5) Anterior view, enlargement area pointed by the upper double-headed arrow in A4 showing the radial lines. (A6) Enlargement view pointed by the lower double-headed arrow in A4 showing the compacted spherical phosphate and compacted phosphate grains. (A7) Enlarged area pointed by the double-headed arrow, showing the microstructure of the shell. (B1,B2) ELI-LWG-6-003. (B1) Ventral valve, exterior view. (B2) Interior view of ventral valve showing the possible muscle scar. (C1) ELI-LWG-6-001, dorsal valve. (C2) Posterolateral view of dorsal exterior, yellow dash line showing different ontogeny stages. (C3) Posterolateral view of dorsal exterior, dash lines showing two pairs of lobes flanking in the metamorphic shell. Abbreviation: pr = protegulum, bs = brephic shell, ns = neanic shell, ps = post-metamorphic shell. 


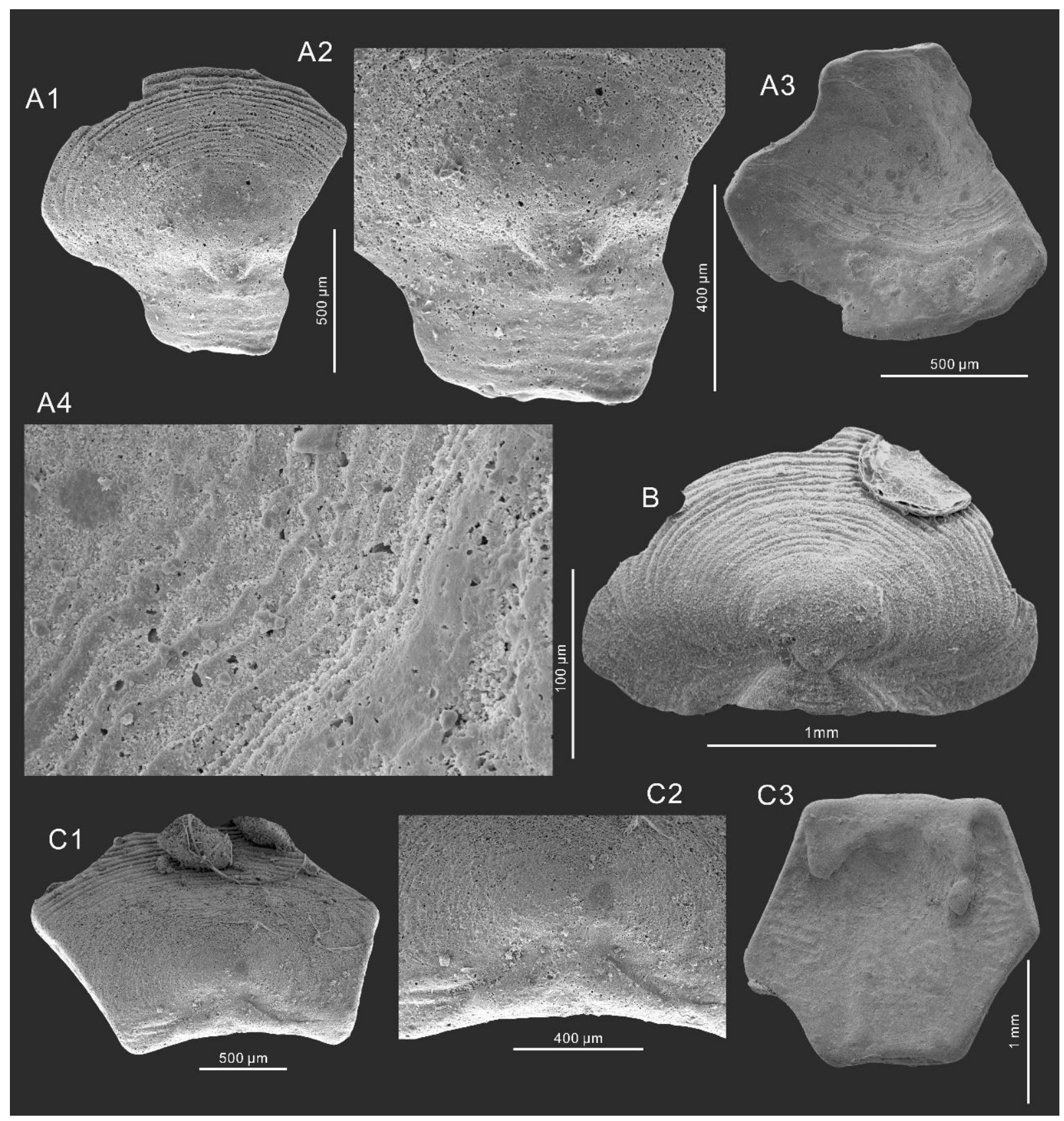

Figure 8. Micromitra sp. from the Hsuzhuang Formation, at the Longwanggou section, Henan Province, North China. (A1) ELI-LWG-10-001, Micromitra sp., ventral valve. (A2) posterolateral view showing the metamorphic shell and the growth line on the homeodeltidium. (A3) Interior view. (A4) Enlarged interior view, showing the lamellar microstructure. (B) ELI-LWG-15-001, Micromitra sp., posterolateral view of ventral exterior showing the metamorphic shell, concentric growth line on the post metamorphic shell and growth line on the homeodeltidium. (C1) ELI-LWG-10-002, Micromitra sp., dorsal valve. (C2) Posterolateral view of dorsal exterior showing the dorsal metamorphic shell and the homeodeltidium. (C3) Interior view. 


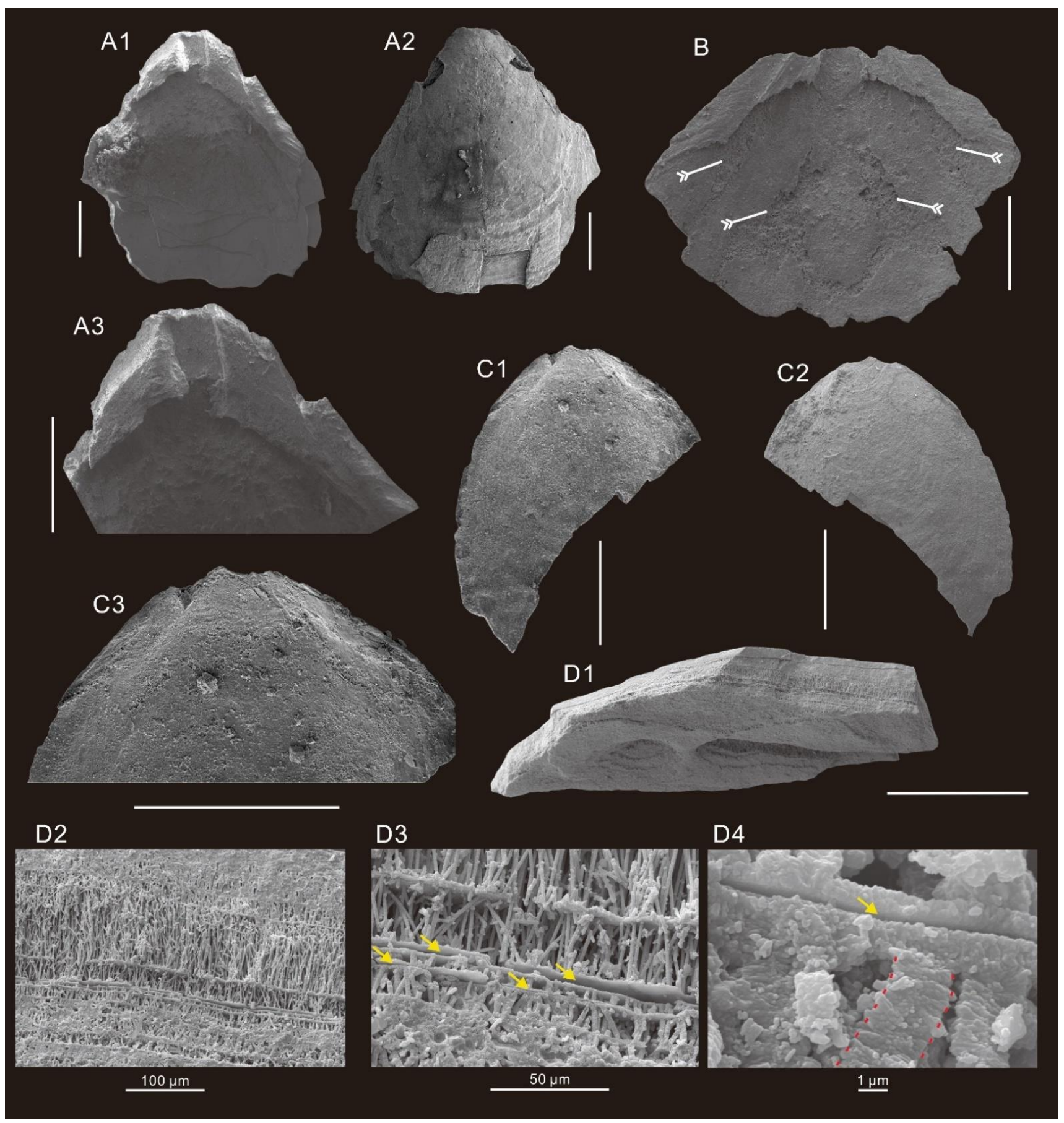

Figure 9. Eoobolus sp. from the middle Cambrian Zhangxia Formation, at the Longwanggou section, Yiyang County, Henan Province, North China. A, ELI-LWG-9-001, ventral view. (A1) Interior view. (A2) Exterior view. (A3) Posterolateral view of ventral valve, showing the pseudointerarea and pedicle groove. (B) ELI-LWG-8C-019, interior view, showing the possible muscle scars, pointed by white arrows, C, ELI- LWG-8-005, dorsal view. (C1), Interior view. (C2) Exterior view. (C3) Posterolateral view of dorsal valve showing the pseudointerarea. D, ELI-LWG-9A-027, Eoobolus sp. (D1) Fragments with the exquisitely preserved shell micro-fabrics. (D2) General view of multiple layers. (D3) Enlarged view of D2, showing the different laminar layers (yellow arrows) and beculate layers. (D4) Enlargement of the laminar layer (yellow arrow) and baculate layers (red dash line) consisting of compacted, oriented phosphate grains (spherulites). All scale bar $=1 \mathrm{~mm}$, except for those labelled. 


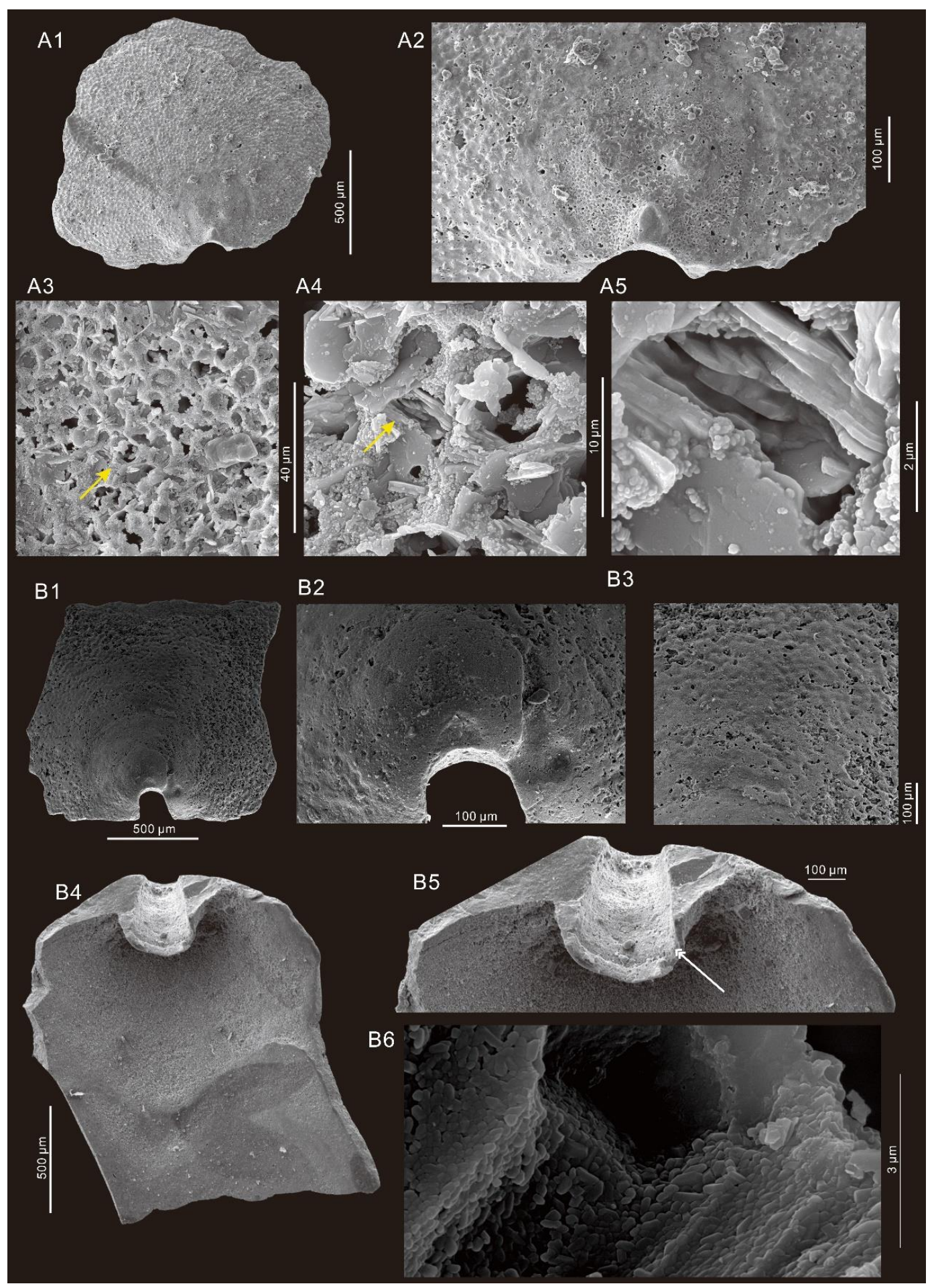

Figure 10. Schizopholis sp. from the middle Cambrian Zhangxia and Hsuzhuang formations, at the Longwanggou section, Yiyang County, Henan Province, North China. (A1-A5), ELI-LWG-15-008, Schizopholis sp. from the Hsuzhuang Formation. (A1) Exterior view of the ventral valve. (A2) Enlarged exterior view, showing the pitted metamorphic shell and the median and lateral pustules. (A3) Enlargement of the metamorphic shell, with pitted ornaments. (A4), Enlarged area pointed by the yellow arrow in A3, pointing the micro structure. (A5) Close-up view pointed by the yellow arrow in A4 with the multiple lamellar, but no compacted phosphate observed. B, ELI-LWG-8C-012, Schizopholis sp. from the Zhangxia Formation. (B1), Exterior view. (B2) Interior view. (B3) Posterolateral view with metamorphic shell and pedicle groove. (B4) Anterolateral view showing the pitted shell ornamentation. (B5) Posterolateral view of the pedicle groove. (B6) Enlargement area pointed by double headed arrow in B5, showing grains stacked and compacted. 
M. modesta is also known from Australia [37], Laurentia [38-40], and South China [41], and Micromitra has a cosmopolitan distribution. Eoobolus, Schizopholis, and Hyolithellus from the NCP are hard to identify at the species level. Oelandiella aliciae and O. accordionat $a$ are mollusks recovered from the Hsuzhuang Formation. O. aliciae is only otherwise known from the Murrawong Creek Formation, Australia [42]. However, O. accordionata is cosmopolitan and it has been recovered from Australia [43], New Zealand [44], and South China [45,46]. M. modesta, O. accordionata, and O. aliciae are three typical species from the lower part of the Murrawong Creek Formation in Australia that are also recovered from the Longwanggou Section. The Murrawong Creek Formation is assigned to the late-middle Cambrian (Undillan-Boomerangian equal to late Drumian to early Guzhuangian) [47]. The similarity of the faunas in the Zhangxia and Hsuzhuang formations and the Murrawong Creek Formation prompts us to propose that these can be roughly correlated chronostratigraphically, belonging to the late Drumian to early Guzhuangian.

\subsection{Global Correlations}

Both palaeomagnetic insights and fossil correlation aspects (especially trilobites, brachiopods and other SSFs) have been used to understand the palaeogeographic location of the NCP, during the latest Ediacaran and the early to middle Cambrian $[8,26,48,49]$. Previous studies point a relatively close palaeogeographic location between the independent NCP continent and the East Gondwana, especially Australia [8,34]. However, detrital zircon age combined with late Cambrian trilobite biogeography support a relatively closer palaeogeographic location between NCP and northeastern India (West Gondwana) [50]. However, the zircon age by $\mathrm{U}-\mathrm{Pb}$ and $\mathrm{Hf}$ isotopic works imply a close palaeogeographic location of NCP and Northern Australia [51]. Pan et al. [8,34] argued for a close palaeogeographic location of NCP with Australia based on early Cambrian SSFs. The study of Pang et al. [49] firstly discovered and reported typical fossils from the Qaidam, late Ediacaran, proposing a close palaeogeographic location of North China and Australia, and the controversy is still going on.

As mentioned before, chancelloriids, echinoderm, and sponge make up a very small percentage of the fauna. Trilobite fragments were recovered from the upper part of the Hsuzhuang Formation; most of them are fragmentary and badly preserved, but they probably represent ptychopterids (Figure 3G,H). The huge amounts of hyoliths without any details on their anatomy structure and shell structure also make them hard to compare with materials from other regions, providing poor support for biostratigraphic correlation.

Linguliform brachiopods are some of the most important components of middle Cambrian skeletal communities, and they are globally distributed in both fine grain siliciclastic and carbonate rocks from the middle Cambrian [1]. As proposed by Zhang et al. [52], both paterinids and linguliforms (reported herein) have a planktonic larval stage, leading to a cosmopolitan distribution [1]. On the other hand, mollusks from the Xinji Formation, North China have previously been successfully used for global palaeogeographic correlation [7]. In this paper, brachiopods and mollusk from the Zhangxia and Hsuzhuang formations were used to shed light on the palaeogeographic reconstructions of NCP.

The SSFs assemblage described here represents the first report of such fauna from middle Cambrian deposits of the region. Despite a relative low diversity of SSFs, some palaeogeographic information still could be achieved. Our cluster analysis using PAST (Figures 11 and 12) showed that the middle Cambrian SSFs assemblage from the Longwanggou section, Central China has the highest similarity with Australia and a relative high similarity with South China (Figure 8). The helcionellids Oelandiella and some of its species are globally distributed, but $O$. aliciae has only been reported from Australia. The discovery of $O$. aliciae from NCP represents its first record outside of Gondwana. The Ediacaran faunas discovered from the Qaidam Basin by Pang et al. [49] also suggest a close palaeogeographic location of Qaidam, South China, North China, and Australia. Besides, North China Platform also has a relatively high similarity with Laurentia, especially in the brachiopod fauna. As proposed by Zhao et al. [48], NCP may link the Laurentia and Aus- 
tralia promoting the exchange of faunas during the middle Cambrian. However, further studies of middle Cambrian faunas from North China are required to determine the more precise palaeogeographic location of NCP.

\begin{tabular}{|c|c|c|c|c|c|c|c|c|c|c|}
\hline \multirow[b]{2}{*}{ Taxa } & \multirow[b]{2}{*}{ 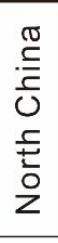 } & \multicolumn{2}{|c|}{ Gondwana } & \multirow{2}{*}{ 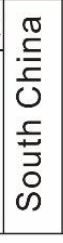 } & \multirow[b]{2}{*}{$\begin{array}{l}\cdot \frac{\sigma}{2} \\
\bar{d} \\
\frac{0}{\omega}\end{array}$} & \multirow[b]{2}{*}{ 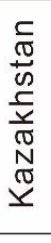 } & \multirow[b]{2}{*}{ 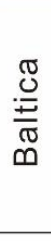 } & \multicolumn{3}{|c|}{ Laurentia } \\
\hline & & 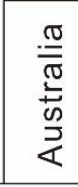 & 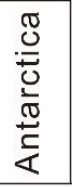 & & & & & 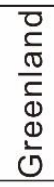 & $\begin{array}{l}\frac{1}{3} \\
\frac{1}{3} \\
3\end{array}$ & 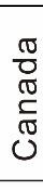 \\
\hline Micromitra sp. & - & $\bullet$ & $\bullet$ & $\bullet$ & $\bullet$ & $\bullet$ & $\bullet$ & $\bullet$ & $\bullet$ & $\bullet$ \\
\hline M. modesta & $\bullet$ & $\bullet$ & & $\bullet$ & & & & $\bullet$ & $\bullet$ & $\bullet$ \\
\hline Eoobolus sp. & $\bullet$ & - & $\bullet$ & $\bullet$ & • & $\bullet$ & $\bullet$ & $\bullet$ & $\bullet$ & $\bullet$ \\
\hline Schizopholis sp. & $\bullet$ & $\bullet$ & $\bullet$ & $\bullet$ & $\bullet$ & $\bullet$ & $\bullet$ & & & \\
\hline Oelandiella aliciae & $\bullet$ & $\bullet$ & & & & & & & & \\
\hline O. accordionata & $\bullet$ & • & - & - & & & & & & \\
\hline Hyolithellus sp. & - & - & - & $\bullet$ & $\bullet$ & $\bullet$ & $\bullet$ & $\bullet$ & $\bullet$ & $\bullet$ \\
\hline Chancelloria eros & $\bullet$ & $\bullet$ & & $\bullet$ & - & & $\bullet$ & $\bullet$ & & $\bullet$ \\
\hline
\end{tabular}

Figure 11. Statistics of skeletal taxa recovered from the Longwanggou Section and comparable to other areas in middle Cambrian. Black dots indicate the presence of species.

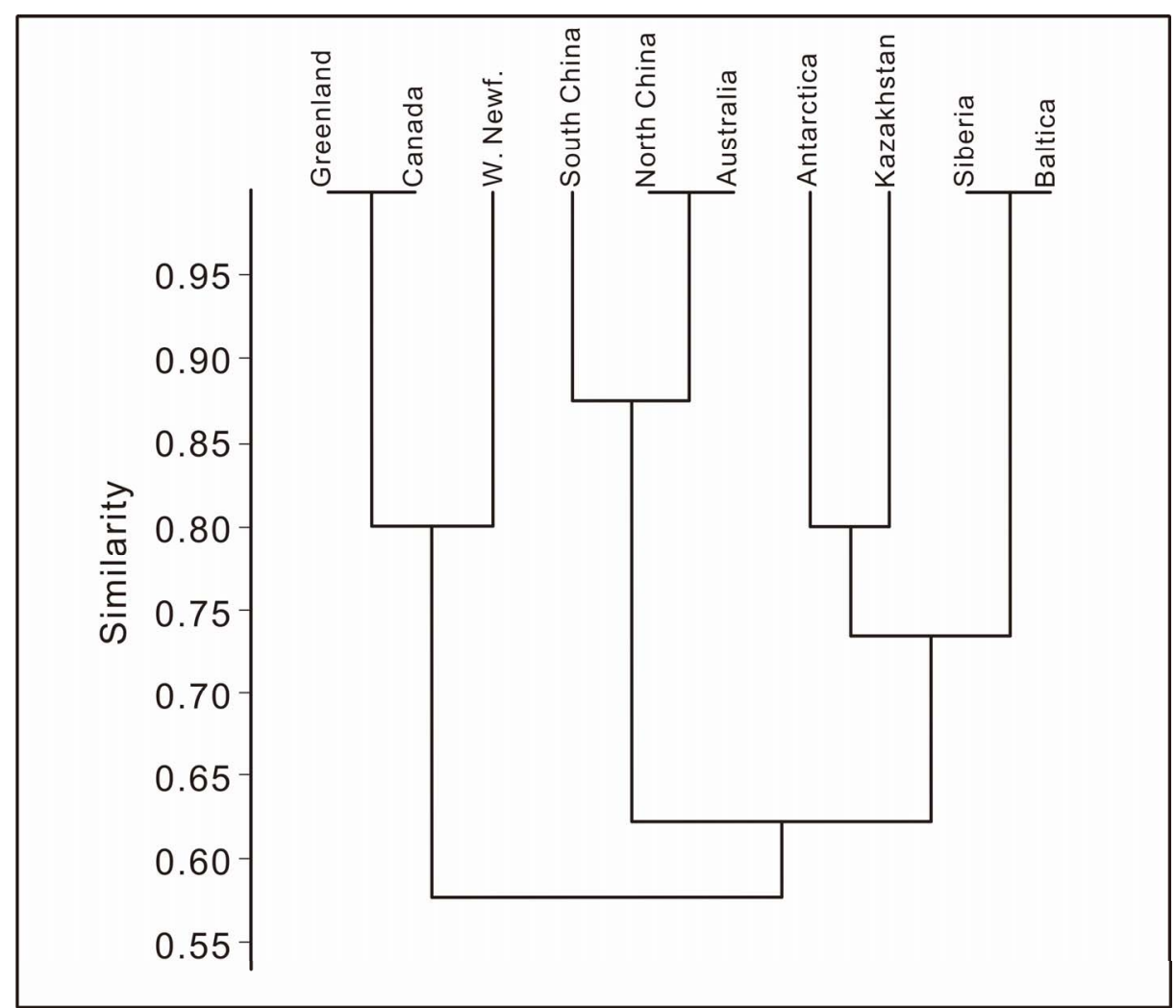

Figure 12. Results of the pair-group cluster analysis (Jaccard similarity) based on the statistic of fossil taxa recovered from the Longwanggou Section and other areas in middle Cambrian, with a high similarity in taxonomic diversity to Australia and South China. 


\section{Systematic Paleontology}

All illustrated specimens are housed and catalogued at Northwest University Early Life Institute (ELI), Department of Geology and State Key Laboratory of Continental Dynamics, Northwest University, Xi'an of China. All the specimen numbers and horizontal levels of the collection samples are labelled in Figure 2A.

- Phylum Brachiopoda Duméril, 1806

- Class Paterinata Williams et al., 1996

- Order Paterinida Rowell, 1965

- Superfamily Paterinoidea Schuchert, 1893

- Family Paterinidae Schuchert 1893

- $\quad$ Genus Micromitra Meek, 1873

Type species. Iphidea? sculptilis Meek, 1873. Middle Cambrian, Montana, USA.

Diagnosis. See Robson et al. [40]

Remarks. Micromitra, Meek, 1873 and its type species, M. sculptilis Meek, 1873 were erected to accommodate paterinids from the middle Cambrian, northern United States of America. Micromitra belongs to paterinids that mainly occur in early and middle Cambrian strata worldwide [37,40,53-58]. A large number of Micromitra have been recovered from both carbonate and mudstone, but the internal structure (e.g., muscle impressions) remains poorly understood.

Well-known occurrences of paterinides (Micromitra and Paterina) are indeed sparse outside Laurentia [59], with some exceptions from the Australasian segment of Gondwana and the Toyonian of Siberia [53,60]. Recently, the fossil records of paterinides in China is increasingly expanding, both in South China and in North China. Wang et al. [61] described several species of Micromitra from the Zhangxia Formation from northeastern China, although their characters are difficult to evaluate based on their photographs and sketchy line drawings. The affinity of Micromitra described by Wang et al. remains open to discussion [61], pending a revision when new material is available for further study.

- Micromitra modesta Lochman, 1940.

Figure 7.

Diagnosis. High delthyrium and shorter notothyrium, homeodeltidium, and minute homeochilidium (See Robson and Pratt [39]).

Examined material. Numerous fragments recovered from sample LWG-6 and several shells from the LWG-10 in the Zhangxia Formation, and 78 more or less fragmentary valves examined here, containing 19 ventral valves, 14 dorsal valves, and 45 fragmentary valves.

Stratigraphy and locality. Lower part to middle part of the Zhangxia Formation, Cambrian Miaolingian in western Henan Province.

Description. The shell is ventribiconvex, transversely subquadrate to circular in commissural outline (Figure 7). All of the available valves are fragmentary, making it difficult to analyze the length:width ratios. It is ornamented with concentric lines on both valves (Figure 7).

The ventral valve is high and gently convex, subquadrate to circular (Figure 7A1-A7,B1,B2). The ventral pseudointerarea extends procline with a rounded beak projecting slightly posterior of hinge line and its apex embedded in homeodeltidium. The ventral metamorphic shell is subcircular and the size ranges from $0.5 \mathrm{~mm}$ to $1 \mathrm{~mm}$ (Figure 7A1,A2), with a flattened posterior margin and prominent rounded beak (Figure 7A1). The ventral metamorphic shell has a clearly distinguished protegulum, brephic, and neanic shell. The protegulum is sub-rounded with a diameter of about $0.3 \mathrm{~mm}$ (Figure 7A2). The rounded brephic shell has two pairs of weakly defined, rounded lobes flanking with the width of each lobe about 0.25 $\mathrm{mm}$ (Figure 7A2). The sub-rounded neanic shell has weak irregular concentric lines (Figure 7A2) and the width of the neanic shell is about $0.15 \mathrm{~mm}$ (Figure 7A2). The remainder of the shell surface is covered by fine, concentric, closely spaced filae, with superimposed weaker radial ridges disrupting and wrinkling the concentric elements (Figure 7A3). The homeodeltidium is moderate and apical, lacking concentric ornamentation (Figure 7B1,B2). 
A single complete dorsal valve is weakly convex, $9.7 \mathrm{~mm}$ in length and $6.0 \mathrm{~mm}$ in width. The dorsal shell is low and subquadrate (Figure 7C1). The dorsal metamorphic shell has one rounded protegulum, one brephic shell (with two paired lobes), and a neanic shell with weak concentric lines (Figure 7C2,C3). The width of dorsal protegulum is about $0.4 \mathrm{~mm}$ (Figure 7C2,C3). The rounded brephic shell has two pairs of clearly defined lobes, about $0.3 \mathrm{~mm}$ in width (Figure 7C3). The sub-rounded dorsal neanic shell has weak concentric lines, but not as continuous as on the post-metamorphic shell (Figure 7C2). The width of the neanic shell is about $0.1 \mathrm{~mm}$ (Figure 7C2).

Pitted ornamentation is missing in both the ventral and dorsal metamorphic shell. Both ventral and dorsal valve interiors of available specimens lack well-defined features, leaving one pair of possible muscle scars (Figure 7B2).

Shell structure. Based on the study of Williams et al. [59], the original shell structure of paterinids (including Micromitra) consists of primary and secondary layers, forming laminar shell structures [62]. The primary layer consists of glycosaminoglycans and spherular apatite, acting as the matrix of later shell lamina. The primary and later secreted laminae constitute the conveyor-belt cycle of the shell secretion [59]. Nevertheless, the shell textures of both ventral and dorsal valves presented in this study are diagentically overprinted (Figure 7A6). It is hard to get the information on mineral secretion process in the Micromitra shell. Occasionally, the interior of the shell is covered by spherulitic phosphorite (Figure 7A6,A7) that are thought to be due to the activity of bacteria and decomposition of organic matter [63].

Remark. The external characters of the shell valves closely resemble those of Micromitra. The Yiyang specimens of Micromitra are similar to M. modesta described and illustrated by Lochman in shell outline [64], convexity, and exterior ornamentation. Compared with M. georginaensis [65], the posterior margin of our specimens appears to be thicker, but not as thick as M. nerranubawu [66]. As for the ventral homeodeltidium, the valves discussed here had relatively smaller homeodeltidium as compared with $M$. nerranubawu, and the Australian species had a larger and extended posterior projection. The new Chinese material differs from M. sculptilis in having distinctly coarser radial costellae, and the minute homeodeltidium and homeochilidium of the new material is clearly different from other species of Micromitra.

Ontogeny. Zhang et al. [52] documented the ontogeny of Eohadrotreta based on materials from the Shuijingtuo Formation, South China and proposed that Eohadrotreta experienced embryo, planktotrophic larva, and post-metamorphically sessile juvenile and adult growth stages. This ontogeny sequence is considered as a plesiomorphic character for most early linguliforms including siphonotretoids, linguloids, mickwitziids, rhynchonelliforms, and paterinates that we discussed herein. The protegulum, brephic shell, neanic shell, and post-metamorphic shell are clearly distinguished based on the M. modesta recovered from the Longwanggou section. M. modesta also experienced embryo, planktotrophic larva, and post-metamorphically sessile (post-metamorphically shell) stages (Figure 7).

- Micromitra sp.

Figure 8.

Examined material. Included 4 ventral valves, 1 dorsal valve, and 142 fragmentary valves including 4 posterior valves, 13 anterior valves, and 125 undistinguished valves from the samples LWG-10, LWG-14, and LWG-15 from the Hsuzhuang Formation.

Stratigraphy and locality. The Hsuzhuang Formation, Cambrian Miaolingian in western Henan Province.

Description. The shell is ventribiconvex (Figure 8). All available valves are more or less fragmentary and complete specimens with homeodeltidium and homeochilidium are absent, making the length:width ratios impossible to determine. Both valves have an ornamentation with concentric lines.

The ventral valve is high and gently convex, subquadrate to circular (Figure 8A1-A4,B). The pseudointerarea profile is procline with a rounded beak, projecting posterior of the hinge line (Figure $8 \mathrm{~A} 1-\mathrm{A} 4, \mathrm{~B}$ ). The homeodeltidium is moderate, and clearly defined with 
evenly spaced concentric fila without fine radial costellae (Figure 8A2,B). The boundary of the ventral metamorphic shell and ventral post-metamorphic shell is weakly defined (Figure 8A1-A4,B). The ventral metamorphic shell is characterized by a smooth shell without any ornamentation. The post-metamorphic shell surface is covered by fine, concentric filae without radial ridges (Figure 8A1,B)). The size of the ventral metamorphic shell ranges from $0.3 \mathrm{~mm}$ to $0.5 \mathrm{~mm}$ (Figure $8 \mathrm{~A} 1-\mathrm{A} 4, \mathrm{~B}$ ).

The dorsal valve is weakly convex, and circular (Figure $8 \mathrm{C} 1$ ). The homeochilidium is small with no ornament (Figure $8 \mathrm{C} 2$ ). The boundary of the dorsal metamorphic shell is not well defined and the ornamentation is poorly preserved (Figure $8 \mathrm{C} 2$ ). The interior of both valves is poorly preserved.

Remark. This material from the Hsuzhuang Formation only comprises concentric lamellae without of the radial ridges. It is too poorly preserved to compare with other species.

- $\quad$ Order Lingulida Waagen, 1885

- Family Eoobolidae Holmer et al., 1996

- Genus Eoobolus Matthew, 1902

Type species. By original designation Obolus (Eoobolus) triparilis Matthew, 1902, middle Cambrian (Bourinot Group), Canada (Cape Breton).

Diagnosis. See Holmer et al. [67].

Remark. Eoobolus is one of the oldest known linguliform brachiopods that co-occurs with the oldest trilobite, Parabadiella huoi [2]. Eoobolus is a globally distributed taxon $[2,14,27,67-70]$. The characters of the metamorphic shell, apical angle in adult ventral valves, and the ornamentations are important diagnostic features for the Eoobolidae [67]. The columnar shell structure is also an important character of Eoobolus.

- Eoobolus sp.

Figure 9.

Examined material. Included 11 ventral valves with preserved pedicle groove, 29 dorsal valves, 16 preserved posterior valves, 41 preserved anterior valves, and 468 undistinguishable fragmentary valves only preserved with concentric filae from the samples LWG-8 and LWG-9 from the Zhangxia Formation.

Stratigraphy and locality. Lower part of the Zhangxia Formation, Cambrian Miaolingian in western Henan Province.

Description. The relatively well-preserved valves suggest a biconvex, elongated subcircular shell with a sub-rounded anterior margin.

The outline of ventral valve is elongate subtriangular, and the length is about $110 \%$ longer than the width, measured from the relative complete ventral valve (Figure 9A1,A2). The ventral valve is moderate convex with straight posterolateral margins enclosing an apical angle from $80^{\circ}$ to $97^{\circ}$ (Figure 9A1-A3,B). Ventral valve pseudointerarea is orthocline (Figure 9A3). The raised ventral valve pseudointerarea is sub-triangular in outline, equally divided by a deep pedicle groove, and the lateral margin of the pedicle groove is almost parallel (Figure 9A3). The ventral valve pseudointerarea overhangs on the valve floor, and is divided by flexure lines which enclose an angle of about $110^{\circ}$ (Figure 9B). The length of the pseudointerarea ranges from $1.09 \mathrm{~mm}$ to $1.94 \mathrm{~mm}$ and the width ranges from $1.53 \mathrm{~mm}$ to $3.80 \mathrm{~mm}$, with the average length:width radio around $169 \%$. The metamorphic shell of both the ventral and dorsal shell is not clearly seen due to the lack of preserved ornamentation (Figure 9A2). The post-metamorphic shell is covered by fine, concentric filae without radial ridges. Impressions of muscles and organs are confined to the visceral area (Figure 9A2). The paired muscle scars are small and run along the entire length of the visceral area from the distal lateral sides of the pedicle groove to the anterior, posterior margin (Figure 9B).

The dorsal valve is slightly convex, suboval in outline (Figure 9C1-C3), and on average $130 \%$ longer than the width. The post-metamorphic shell is covered by fine, concentric filae without radial ridges (Figure 9C2). The width of pseudointerarea is about 300\% longer 
than long, with a broad, shallow median groove (Figure 9C3). Visceral area is un-preserved; muscle scars are poorly marked.

Shell structure. The shell of the Eoobolus sp. from the Longwanggou section is about $0.5 \mathrm{~mm}$ thick in the center (Figure 9D1). In general, the shell structures consist of primary laminar layers and secondary columnar layers (Figure 9D2-D4). The primary laminar layers are composed of tightly compacted phosphorite grains, with sizes of about $1 \mu \mathrm{m}$ (Figure 9D4). The thickness of the primary layers is about $1 \mu \mathrm{m}$ (Figure 9D4). The thickness of the secondary columnar layer depends on the length of columns forming the secondary columnar layers. The length of these columnar ranges from $5.5 \mu \mathrm{m}$ to $83.0 \mu \mathrm{m}$ (Figure 9D2,D3). Both the primary and secondary columnar layers consist of the tightly compacted phosphorite grains (Figure 9D4). The phosphorite grains are about $1 \mu \mathrm{m}$ in length and elongated polyhedral in outline.

The columnar shell structure is well-known in linguloid brachiopods, including Eoobolidae, Linguloidea, Zhanatellidae, Kyrshabaktellidae, and Acrotretidae [71]. The shell of these organophosphatic brachiopods is comprised of an organic periostracum, a mineralized laminar layer (primary layer), and a secondary columnar layer [71]. The secondary shell of Eoobolus examined here appears to be baculite, most likely resembling those seen in lingulide brachiopods. In recent studies, Duan et al. reported the columnar shell structure of acrotretoid from early Cambrian mudstones, South China, representing the best counterpart for columnar shell fabrics from carbonate [18]. The secondary columnar pillars (hollow tube [18]) could have contained unmineralized organic fibers. It is widely accepted that the growth of brachiopods shells mainly depends on the mantle epithelial cells, membrane, and inter-crystalline organic matrix [72-74]. Analogously, the biomineralization process of Eoobolus sp. depends on membrane-controlled mechanisms. Although the original minerals are overprinted, the membrane in Eoobolus sp. acts as the template or scaffold for both primary and secondary layers. Then, the bioapatite precipitate near the membrane forms the baculate shell structure as the shell structures seen in acrotretids. The columnar shell structure from mudstone [18] probably represents the original shell textures constrained by the organic epithelial membrane that are replaced by clay minerals during later diagenesis. By contrast, the baculate structures reported herein were slightly intercrossing and with no inner hollow tube inside (Figure 9D4). Both the primary layer and the secondary columnar layer were constituted with elongated polyhedral grains (Figure 9D4). The origin of the phosphorite grains are thought to be the secondary diagenesis $[2,69]$. The decomposition of earlier phosphorite or organic matters may cause the supersaturation of apatite solution, leading to the recrystallization of apatite within the hollow tubes and the primary layers. The coarse-grained preservation and the acetic acid maceration of the bioclastic limestone could make the original membranous laminae disappear, leaving the well oriented, elongated polyhedral grains in both the primary layer and secondary baculate layer.

Remark. The apical angle of adult ventral valves is the most stable character for taxonomic work within Eoobolus. The apical angle of ventral valve from the Zhangxia Formation ranges from $80^{\circ}$ to $97^{\circ}$, which is similar to many species of Eoobolus, for example, Eoobolus sp. in Betts et al. [75], E. viridis in Zhang et al. [2], and E. priscus in Poulsen [76]. Due to the lack of complete materials, it is hard to assign this type to any known species.

- Superfamily Acrotheloidea Walcott and Schuchert in Walcott, 1908

- $\quad$ Family Botsfordiidae Schindewolf, 1955

- Genus Schizopholis Waagen, 1885

- 1885 Discinolepis Waagen

- 1986 Karathele Koneva

Type species. Schizopholis rugosa Waagen, 1885, lower Cambrian, Khussak Formation (lower Neobolus beds), Salt Range, Pakistan.

Diagnosis. See Popov et al. [60].

Remark. Schizopholis is a widely distributed brachiopod genus in early and middle Cambrian and it has been recovered from Himalaya, Kazakhstan, Australia, Antarctica, 
South China, and North China [9]. Popov et al. [60] regard Schizopholis as a key role in the evolutionary lineage of Botsfordia, Schizopholis, Eothele, and Acrothele. The record of Schizopholis from the Zhangxia Formation at Longwanggou section extend the distribution of this genus.

- Schizopholis sp.

Figure 10.

Examined material. One ventral valve and four fragmentary shells from the samples LWG-8 and LWG-9 from the Zhangxia Formation, and one ventral valve from sample LWG-15 from the Hsuzhuang Formation.

Stratigraphy and locality. Lower part of the Hsuzhuang Formation and lower part of the Zhangxia Formation, Cambrian Miaolingian in western Henan Province.

Description. Shell is ventribiconvex and subcircular in outline (Figure 10A1-A5,B1-B6). All of the specimens are fragmentary, making it hard to determine the length:width radio. Both ventral and dorsal valves are ornamented with pustulose granules, and with weak concentric growth lines (Figure 10A1,B1).

The ventral valve is subcircular and convex (Figure 10A1-A5,B1-B6), and the pseudointerarea is procline and very deep, forming an oval opening (Figure 10A1,B1). The width of the pedicle groove is about $0.1 \mathrm{~mm}$. The metamorphic shell is oval in outline and about $0.38 \mathrm{~mm}$ in length and $0.32 \mathrm{~mm}$ in width and with pitted ornaments (Figure 10A2). There are two protuberances posterolaterally on the ventral valve brephic shell, and one protuberance on the protegulum (Figure 10A2).

Shell structure. Although Schizopholis has been recovered from many localities [8,9,77], the shell structure of Schizopholis is rarely studied and hard to determine. Schizopholis yorkensis is from east Antarctica, with several photographs showing a lamellar microstructure (Figure 9S in Claybourn et al. [78]). Two different shell structures were observed in Schizopholis sp. from the Longwanggou section. The first shell structures were lamellar microstructures without any columnar structure occurring around the pustulose granules and pitted ornaments (Figure 10A3,A4). More than 10 lamellar microstructures were found around the pitted ornaments. The thickness of the single lamellar is about $0.15 \mu \mathrm{m}$ (Figure 10A5). The surface of the lamellar microstructures is smooth with no phosphate grains preserved (Figure 10A5). The other shell structures were tightly compacted, elongated phosphate grains (ca. $0.5 \mu \mathrm{m}$ in length and $0.2 \mu \mathrm{m}$ in width) forming a homogeneous shell (Figure 10B4-B6). This structure could be due to the decomposition and recrystallization of earlier phosphorite [2,69]. The shell structure of Schizopholis sp. distinctly differs from the other brachiopods recovered from the Longwanggou section. This may be due to the different biomineralization templates of Schizopholis that are controlled by the secretion of inter-crystalline organic matrix. Future works are needed to make clear the shell mineralization process of Schizopholis.

Remark. The available fragmentary shells make closer taxonomic discrimination impossible. Species of Schizopholis can be determined, mainly on the morphology of the ventral pseudointerarea, which is not available here. The pitted ornamentation of the shell strongly assigns it to Acrotheloidea and the occurrence of the pedicle groove resembles this specimen to Schizopholis. However, the lack of complete ventral pseudointerarea makes it hard to determine the species.

- $\quad$ Phylum Mollusca Cuvier, 1795

- Class Helcionelloida Peel, 1991

- $\quad$ Order Helcionellida Geyer, 1994

- Family Helcionellidae Wenz, 1938

- Genus Oelandiella Vostokova, 1962

Type species. Oelandiella korobkovi Vostokova, 1962 from the lower Cambrian of the Kotuj River, north Siberia.

Diagnosis. See Gubanov and Peel [79]. 
Remark. Latouchella, Oelandiella and Oelandia belong to helcionellids and show great similarities in morphology and ornaments with each other. Gubanov and Peel [79] proposed a detailed taxonomic work about Latouchella, Oelandiella, and Oelandia based on the occurrence of the ribs versus the dorsum. Oelandiella is clearly distinguished from the other two genus by the symmetrical commarginal ribs crossing the dorsum. Latouchella is characterized by the ribbed lateral area and a smooth dorsum. Oelandia differs from them by the asymmetrically arranged ribs. Many studies accepted this taxonomy and Oelandiella was found in some new localities, including South China [45,46].

- Oelandiella accordionata Runnegar and Jell, 1976.

Figure 4A1,A2,B,C,D1,D2.

1976 Latouchella accordionata Runnegar and Jell, p. 48, pl. 23, figs. A-M.

2012 Oelandiella cf. accordionata Runnegar and Jell, Yang et al., p. 317, pl. 1, figs. 1-12.

Examined material. Six relative well-preserved shells and six fragmentary shells recovered from the sample LWG-11 from the upper part of the Hsuzhuang Formation.

Stratigraphy and locality. Upper part of the Hsuzhuang Formation, Cambrian Miaolingian in western Henan Province.

Description. Most of the specimens are preserved as interior mound (Figure 4), but broken argillaceous outer mound is rarely found too (Figure 4F1). Shell is moderate high, cyrtoconic, and characterized by univalves (length ranges from 1-3 mm) with simple, regularly spaced, angular commarginal rugae crossing the whole ridge of the shell (Figure 4A1,A2,B,C,D1,D2). These commarginal rugae are loosely coiled, forming a whorl-shaped shell. The shell aperture is planar, with an oval to subrectangular outline (Figure 4E1). Fine radial ornaments are preserved on the argillaceous inner mounds (Figure 4F1). The inner surface of sub-apical shell wall occurs with a pair of uniformly thin ridges (Figure $4 \mathrm{~B}, \mathrm{C}$ ).

Remark. Specimens occurring as inner and outer mounds in the Hsuzhuang Formation are conspecific with O. accordionata from the Coonigan and Murrawong Creek formations in Australia and the Tsinghsutung and Jialao formations in South China for the tall, compressed cyrtoconic univalves with a subrectangular character. The O. accordionata recovered from the Longwanggou Section, middle Cambrian, represents the first report of O. accordionata as well as Oelandiella from the North China Platform. The size of $O$. accordionata reported here is smaller than earlier materials from the Murrawong Creek Formation [42].

- Oelandiella aliciae Brock, 1998.

Figure 4E.

- 1976 Latouchella accordionata Runnegar \& Jell, figs. 10C.

- 1998 Latouchella aliciae Brock, figs. 3.7-12; 4.1-3.

Type species. Latouchella aliciae Brock, 1998.

Diagnosis. See Brock [42].

Examined material. One relatively well-preserved shell recovered from the sample LWG-11 from the upper part of the Hsuzhuang Formation.

Stratigraphy and locality. Upper part of the Hsuzhuang Formation, Cambrian Miaolingian in western Henan Province.

Description. The shell is moderately involute, with robust univalves with a shell length around $3 \mathrm{~mm}$ and height around $2 \mathrm{~mm}$ (Figure 4E1,E2). The shell is composed of moderate, coiled commarginal rugae forming a whorl-shaped shell in outline (Figure 4E2). These rugae are separated by a wide interrugal space. The biggest interrugal spaces on the supra-apical surface decrease to the posterior (Figure 4E2). The shell aperture is planar, with a subrectangular outline (Figure 4E1). The pair of narrow ridges occurs on the inner subapical margin (Figure 4E2). No ornamentation is preserved except for the commarginal rugae.

Remark. Comparing with the other species of Oelandiella, the specimen described here should be assigned to $O$. aliciae for its sharply angular character. Comparing with the other 
species of Oelandiella, the distribution of $O$. aliciae is restricted. In early research, $O$. aliciae is erected based on specimens from Murrawong Creek Formation, Australia [42]. The $O$. aliciae found in the Hsuzhuang Formation, at Longwanggou section, Central China, represents the first locality out of the Gondwana, suggesting a relatively close palaeogeographic position of NCP and Australia during the middle Cambrian.

- Order Hyolithelminthida Fisher, 1962

- Family Hyolithellidae Walcott, 1886

- Genus Hyolithellus Billings, 1871

- Hyolithellus sp.

Figure 6A,B1,B2.

Examined material: Included 129 fragmentary tube sections from sample LWG-12 from the Hsuzhuang Formation

Stratigraphy and locality. Middle part of the Hsuzhuang Formation, Cambrian Miaolingian in western Henan Province.

Description. The shell is circle shaped in the cross section, and straight or slightly curved in the longitudinal (Figure 6A,B1,C1-C3). A few tubes occur with annulate ornamentations (Figure $6 \mathrm{~A}, \mathrm{~B} 1$ ). In the cross section, the annulate ornaments are actually overlapped lamellar structures and the thickness of each lamellar is about $5 \mu \mathrm{m}$ (Figure 6B2,C2). Besides, the lamellar is composed of tightly compacted phosphate grains (Figure 6C3). On the average, the tube exhibits about 12 annulations per $\mathrm{mm}$ with individual annulations varying from 50 to $75 \mu \mathrm{m}$ (Figure 6A,B1).

Remark. Hyolithellus represents a tube-like fossil that has remained problematic. These tubes are globally distributed and are commonly seen in a wide range of sedimentary deposits of the early and middle Cambrian. Specimens of Hyolithellus have been found in life position from lower Cambrian dolostone and are regarded as the possible stem group of annelids [80]. However, it is hard to identify species of Hyolithellus only based on the morphology of an individual $[80,81]$. The new record of Hyolithellus sp. from the Hsuzhuang Formation represents its first report from the NCP, extending its paleogeography distribution.

- Phylum Uncertain

- Class Hyolitha Marek, 1963

- Hyolithid sp. Indet

Figure 3A-D.

Examined material. Included 2273 calcitic inner molds from the Zhangxia Formation and 1 inner mold from the Hsuzhuang Formation.

Stratigraphy and locality. The Zhangxia and Hsuzhuang formations, Cambrian Miaolingian in western Henan Province.

Remark: Hyoliths are the most abundant organisms in acid residues, but all of them are exclusively represented by internal molds of the conical conchs. Those indeterminable hyolithids, preserved as internal molds with subtriangular cross-sections, are common throughout the Zhangxia Formation (Figure 3A,B,D). The specimen from the Hsuzhuang Formation with a sub-circle cross-section could be another species (Figure 3C). Betterpreserved samples are required to perform taxonomic work, rather than on these calcitic internal molds.

- $\quad$ Phylum Echinodermata Bruguière, 1791

- INDET. Echinoderm ossicles

Figure 3E1,E2.

Material. Three specimens from the sample LWG-15 from the lower part of the Hsuzhuang Formation.

Stratigraphy and locality. The lower part of the Hsuzhuang Formation, Cambrian Miaolingian in western Henan Province. 
Remark. The samples are actually preserved as secondary phosphatic infill of the cavities of echinoderm stereom structure (Figure 3E1,E2) [81]. It is hard to perform any taxonomic work based on the echinoderm ossicles.

- $\quad$ Phylum Porifera Grant, 1872

- Class, Order, Family, Genus and Species unassigned

- Sponge spicule

Figure 3F.

Material. One isolated fragmentary spicule from sample LWG-15 from the Hsuzhuang Formation.

Stratigraphy and locality. The lower part of the Hsuzhuang Formation, Cambrian Miaolingian in western Henan Province.

Remark. Spicules with three rays diverge at $90^{\circ}$ from each other in a single plane. This specimen is preserved as argillaceous with no surface details observed (Figure 3F). The poor and rare preservation restrict taxonomic evaluation.

- Phylum and Class uncertain

- Order Chancelloriida Walcott, 1920

- Genus Chancelloria Walcott, 1920

- Chancelloria eros Walcott, 1920

Figure 5.

Examined material. Twenty sclerites recovered from the sample LWG-9 from the Zhangxia Formation.

Stratigraphy and locality. The lower part of the Zhangxia Formation, Cambrian Miaolingian in western Henan Province.

Remark. Most of the chancelloriid sclerites are fragmentary calcitic internal molds that are identified as single, isolated lateral rays and central, vertical rays (Figure 5). The relatively well-preserved star-shaped sclerites with a rosette of lateral rays surrounding a central $(7+1)$ ray resemble Chancelloria eros Walcott, 1920 (Figure 5F-H). Chancelloria are a globally distributed genus from the early Cambrian to the late Cambrian. It is not the first discovery of Chancelloriidae in the NCP. Before then, amounts of Chancelloriidae were recovered from the Xinji Formation, lower Cambrian [32]. Chancelloriidae also have been reported from the Mantou, Zhangxia, and Changshan formations at NCP [21].

\section{Conclusions}

Middle Cambrian small shelly fossils were described from the Zhangxia and the Hsuzhuang formations at the Longwanggou section. The fauna included brachiopods (Micromitra sp., M. modesta, Eoobolus sp., and Schizopholis sp.), helcionelloid (Oelandiella accordionata and O. aliciae), Hyolithellus, Chancelloria eros, Chancelloriidae sclerites, hyolithid, sponge spicule, and echinoderm ossicles. The shell structures of M. modesta, Eoobolus sp., Schizopholis sp., Oelandiella accordionata, and Hyolithellus were described. The shell structure of M. modesta is composed of a homogeneous layer consisting of tightly compacted phosphate grains. Eoobolus sp. is composed of primary layer and secondary columnar structure, and both of them are composed of tightly compacted phosphate grains. Schizopholis sp. has multiple-lamellar microstructures differing from other coeval brachiopods retrieved from the Longwanggou section. Lamellar excretions of multiple-layer microstructures also occur in Hyolithellus that are preserved with tightly compacted phosphate grains. The argillaceous Oelandiella accordionata and O. aliciae, and the calcitic inner molds of hyolith preserved no clear shell structure. The helcionellid O. accordionata, O. aliciae, and M. modesta were recorded for the first time from the North China Platform. The fauna showed similarities to the middle Cambrian faunas of Australia and South China, but also to Laurentian faunas. The biological assemblage suggests that the palaeogeographic location of the North China Platform and Australia may have been relatively close in location to South China. The age of the small shelly fauna ranged from late Drumian to middle Guzhuangian and may have a similar age to the Murrawong Creek Formation in Australia. 
Author Contributions: Conceptualization, Z.Z.; data curation, Y.H.; formal analysis, Y.H.; funding acquisition, Z.Z.; methodology, Y.H., Y.L., X.D. and Z.Z.; project administration, Z.Z.; resources, Y.H. and Z.Z.; supervision, Z.Z.; writing-original draft, Y.H.; writing-review and editing, L.E.H. and Z.Z. All authors have read and agreed to the published version of the manuscript.

Funding: This research was funded by National Natural Science Foundation of China, grant number 41720104002, 41890844, 41425008, and the Strategic Priority Research Program of the Chinese Academy of Sciences award to the Early Life Institute (XDB26000000) and the 111th project (D17013) funding at Northwest University. L.E.H was funded by the Swedish Research Council (VR Project no. 2018-03390) and by a Zhongjian Yang Scholarship from the Department of Geology, Northwest University, Xi'an.

Data Availability Statement: Not applicable.

Acknowledgments: We thank Zhai J. P., and Zhang D. D., for their kindly helps in field work and sample collecting. Chen Y.L. is acknowledged for his suggestions and review on the manuscript. The authors also want to thank Luo M. and Chen S. for their kindly help in SEM analyses.

Conflicts of Interest: The authors declare no conflict of interest.

\section{References}

1. Zhang, Z.F.; Zhang, Z.L.; Li, G.X.; Holmer, L.E. The Cambrian Brachiopod Fauna from the First-Trilobite Age Shuijingtuo Formation in the Three Gorges Area of China. Palaeoworld 2016, 25, 333-355. [CrossRef]

2. Zhang, Z.; Ghobadi Pour, M.; Popov, L.E.; Holmer, L.E.; Chen, F.; Chen, Y.; Brock, G.A.; Zhang, Z. The Oldest Cambrian Trilobite-Brachiopod Association in South China. Gondwana Res. 2021, 89, 147-167. [CrossRef]

3. Pei, F. First Discovery of Yochelcionella from the Lower Cambrian in China and Its Significance. Acta Micropalaeontol. Sin. 1985, 2, 395-401.

4. Li, L.; Zhang, X.; Skovsted, C.B.; Yun, H.; Pan, B.; Li, G. Homologous Shell Microstructures in Cambrian Hyoliths and Molluscs. Palaeontology 2019, 62, 515-532. [CrossRef]

5. Li, L.; Zhang, X.; Skovsted, C.B.; Yun, H.; Li, G.; Pan, B. Shell Microstructures of the Helcionelloid Mollusc Anabarella australis from the Lower Cambrian (Series 2) Xinji Formation of North China. J. Syst. Palaeontol. 2019, 17, 1479-1489. [CrossRef]

6. Li, L.; Skovsted, C.B.; Yun, H.; Betts, M.J.; Zhang, X. New Insight into the Soft Anatomy and Shell Microstructures of Early Cambrian Orthothecids (Hyolitha): Anatomy and Biomineralization. Proc. R. Soc. B 2020, 287, 1-10. [CrossRef] [PubMed]

7. Li, L.; Zhang, X.; Skovsted, C.B.; Yun, H.; Pan, B.; Li, G. Revisiting the Molluscan Fauna from the Cambrian (Series 2, Stages 3-4) Xinji Formation of North China. Pap. Palaeontol. 2021, 7, 521-564. [CrossRef]

8. Pan, B.; Skovsted, C.B.; Brock, G.A.; Topper, T.P.; Holmer, L.E.; Li, L.Y.; Li, G.X. Early Cambrian Organophosphatic Brachiopods from the Xinji Formation, at Shuiyu Section, Shanxi Province, North China. Palaeoworld 2020, 29, 512-533. [CrossRef]

9. Chen, F.; Zhang, Z.; Betts, M.J.; Zhang, Z.; Liu, F. First Report on Guanshan Biota (Cambrian Stage 4) at the Stratotype Area of Wulongqing Formation in Malong County, Eastern Yunnan, China. Geosci. Front. 2019, 10, 1459-1476. [CrossRef]

10. Fu, D.; Tong, G.; Dai, T.; Liu, W.; Yang, Y.; Zhang, Y.; Cui, L.; Li, L.; Yun, H.; Wu, Y.; et al. The Qingjiang Biota-A Burgess Shale-Type Fossil Lagerstätte from the Early Cambrian of South China. Science 2019, 1342, 1338-1342. [CrossRef]

11. Shu, D.; Han, J. Core Value of the Chengjiang Fauna: Formation of the Animal Kingdom and the Birth of Basic Human Organs. Earth Sci. Front. 2020, 27, 382-412. [CrossRef]

12. Duan, X.; Liang, Y.; Holmer, L.E.; Zhang, Z. First Report of Acrotretoid Brachiopod Shell Beds in the Lower Cambrian (Stage 4) Guanshan Biota of Eastern Yunnan, South China. J. Paleontol. 2021, 95, 40-55. [CrossRef]

13. Zhang, Z.; Strotz, L.C.; Topper, T.P.; Chen, F.; Chen, Y.; Liang, Y.; Zhang, Z.; Skovsted, C.B.; Brock, G.A. An Encrusting Kleptoparasite-Host Interaction from the Early Cambrian. Nat. Commun. 2020, 11, 1-8. [CrossRef] [PubMed]

14. Zhang, Z.; Holmer, L.E.; Liang, Y.; Chen, Y.; Duan, X. The Oldest 'Lingulellotreta' (Lingulata, Brachiopoda) from China and Its Phylogenetic Significance: Integrating New Material from the Cambrian Stage 3-4 Lagerstätten in Eastern Yunnan, South China. J. Syst. Palaeontol. 2020, 18, 945-973. [CrossRef]

15. Peng, J.; Zhao, Y.; Wu, Y.; Yuan, J.; Tai, T. The Balang Fauna-A New Early Cambrian Fauna from Kaili City, Guizhou Province. Chin. Sci. Bul. 2005, 50, 1055-1057. (In Chinese) [CrossRef]

16. Zhang, X.; Liu, W.; Zhao, Y. Cambrian Burgess Shale-Type Lagerstätten in South China: Distribution and Significance. Gondwana Res. 2008, 18, 255-262. [CrossRef]

17. Zhang, Z.; Zhang, Z.; Holmer, L.E.; Li, G. First Report of Linguloid Brachiopods with Soft Parts from the Lower Cambrian (Series 2, Stage 4) of the Three Gorges Area, South China. Annales Paléontologie 2015, 101, 167-177. [CrossRef]

18. Duan, X.; Betts, M.J.; Holmer, L.E.; Chen, Y.; Liu, F.; Liang, Y.; Zhang, Z. Early Cambrian (Stage 4) Brachiopods from the Shipai Formation in the Three Gorges Area of South China. J. Paleontol. 2021, 95, 497-526. [CrossRef]

19. Wang, Y.; Huang, D.; Lieberman, B.S. New Isoxys (Arthropoda) from the Cambrian Mantou Formation, Shandong Province. Acta Palaeontol. Sin. 2010, 49, 398-406, (In Chinese with English Abstract). 
20. Han, Y.; Wang, P.; Mao, Y.; Gao, J. New Material of Nisusia Walcott, 1905 from the Manto Formation (2-3 Series, Cambrian), Tangshan, Hebei Province. Acta Palaeontol. Sin. 2018, 57, 295-303, (In Chinese with English Abstract).

21. Han, Q.; Li, G.; Wang, P.; Gao, J.; Zhang, T.; Sun, Z. New Material of Chancelloriids from Cambrian, North China. Geol. J. China Univ. 2019, 25, 633-640, (In Chinese with English Abstract). [CrossRef]

22. Liu, Y.; Sun, Z.; Zeng, H.; Zhao, F. Brachiopods from the Upper Part of the Mantou Formation (Cambrian, Miaolingian, Wuliuan) in Weifang, Shandong, North China. Acta Palaeontol. Sin. 2021, 60, 150-165, (In Chinese with English Abstract). [CrossRef]

23. Sun, Z.; Zeng, H.; Zhao, F. Digestive Structures in Cambrian Miaolingian Trilobites from Shandong. Acta Palaeontol. Sin. 2021, 60, 166-175, (In Chinese with English Abstract). [CrossRef]

24. Mei, S. Middle and Upper Cambrian Inarticulate Brachiopods from Wanxian, Hebei, North China. Acta Palaeontol. Sin. 1993, 32, 400-439, (In Chinese with English Abstract).

25. Park, T.Y.; Woo, J.; Lee, D.J.; Lee, D.C.; Lee, S.B.; Han, Z.; Chough, S.K.; Choi, D.K. A Stem-Group Cnidarian described from the mid-Cambrian of China and its significance for Cnidarian evolution. Nat. Commun. 2011, 2, 442. [CrossRef] [PubMed]

26. Yun, H.; Zhang, X.; Li, L.; Zhang, M.; Liu, W. Skeletal Fossils and Microfacies Analysis of the Lowermost Cambrian in the Southwestern Margin of the North China Platform. J. Asian Earth Sci. 2016, 129, 54-66. [CrossRef]

27. Pan, B.; Skovsted, C.B.; Sun, H.; Li, G. Biostratigraphical and Palaeogeographical Implications of Early Cambrian Hyoliths from the North China Platform. Alcheringa 2019, 43, 351-380. [CrossRef]

28. Hammer, Ø.; Harper, D.A.T.; Ryan, P.D. PAST: Paleontological Statistics Software Package for Education and Data Analysis. Palaeontol. Electro. 2001, 4, 1-9.

29. Pei, F. The Cambrian of North China Type in Henan Province. Reg. Geol. China 1991, 3, 210-220.

30. Pei, F. Division and Correlation of the North China Type Cambrian Biostratigraphic Units of Henan Province. Henan Geol. 2000, 18, 97-106.

31. Liu, Q.; Huang, D.; Gong, Y. Sponge Fossils from the Cambrian Mantou Formation of Hebei, Henan, Central China. Earth Sci. J. China Univ. Geosci. 2012, 37, 129-135, (In Chinese with English Abstract).

32. Yun, H.; Zhang, X.; Brock, G.A.; Li, L.; Li, G. Biomineralization of the Cambrian Chancelloriids. Geology 2021, 49 , 623-628. [CrossRef]

33. Pan, B.; Brock, G.A.; Skovsted, C.B.; Betts, M.J.; Topper, T.P.; Li, G. Paterimitra pyramidalis Laurie, 1986, the First Tommotiid Discovered from the Early Cambrian of North China. Gondwana Res. 2018, 63, 179-185. [CrossRef]

34. Pan, B.; Topper, T.P.; Skovsted, C.B.; Miao, L.; Li, G. Occurrence of Microdictyon from the Lower Cambrian Xinji Formation along the Southern Margin of the North China Platform. J. Paleontol. 2018, 92, 59-70. [CrossRef]

35. Li, L.; Zhang, X.; Yun, H.; Li, G. Complex Hierarchical Microstructures of Cambrian Mollusk Pelagiella: Insight into Early Biomineralization and Evolution. Sci. Rep. 2017, 7, 1-11. [CrossRef] [PubMed]

36. Holmer, L.E.; Popov, L.E. Class Lingulata. In Treatise on Invertebrate Paleontology, Part H, Brachiopoda (Revised), Part 2; Williams, A., Brunton, C.H.C., Carlson, S.J., Eds.; University of Kansas Press: Lawrence, KS, USA, 2000; pp. 20-146.

37. Engelbretsen, M.J. Middle Cambrian Lingulate Brachiopods from the Murrawong Creek Formation, Northeastern New South Wales. Hist. Biol. 1996, 11, 69-99. [CrossRef]

38. Zell, M.G.; Rowell, A.J. Brachiopods of the Holm Dal Formation (Late Middle Cambrian), Central North Grenland. Meddr. Grønland. Geosci. 1988, 20, 119-144.

39. Robson, S.P.; Pratt, B.R. Cambrian and Ordovician Linguliform Brachiopods from the Shallow Bay Formation (Cow Head Group), Western Newfoundland. J. Paleontol. 2001, 75, 241-260. [CrossRef]

40. Robson, S.P.; Nowlan, G.S.; Pratt, B.R. Middle to Upper Cambrian Linguliformean Brachiopods from the Deadwood Formation of Subsurface Alberta and Saskatchewan, Canada. J. Paleontol. 2003, 77, 201-211. [CrossRef]

41. Engelbretsen, M.J.; Peng, S. Middle Cambrian (Wulingian) Linguliformean Brachiopods from the Paibi Section, Huaqiao Formation, Hunan Province, South China. Mem. Assoc. Australas. Palaeontol. 2007, 34, 311-329.

42. Brock, G.A. Middle Cambrian Molluscs from the Southern New England Fold Belt, New South Wales, Australia. Geobios 1998, 31, 571-586. [CrossRef]

43. Runnegar, B.; Jell, P.A. Australian Middle Cambrian Molluscs and Their Bearing on Early Molluscan Evolution. Alcheringa 1976, 1, 109-138. [CrossRef]

44. Pojeta, J.; Simes, J.E.; Cooper, R.A. New Zealand Cambrian and Ordovician Micromolluscs. Mem. Assoc. Australas. Palaeontol. 2014, 1, 1-16.

45. Yang, Y.; Zhao, Y.; Peng, J.; Yang, X. Oelandiella from the Cambrian Tsinghsutung Formation of Jianhe County, Guizhou. Acta Palaeontol. Sin. 2012, 51, 308-319, (In Chinese with English Abstract). [CrossRef]

46. Duan, X.; Yang, X.; Wang, Y. Oelandiella from the Cambrian Jialao Formation of Guizhou, China. Acta Palaeontol. Sin. 2017, 56, 529-537. [CrossRef]

47. Percival, I.G.; Quinn, C.D.; Brock, G.A. A Review of Cambrian and Ordovician Stratigraphy in New South Wales. Q. Notes Geol. Surv. N. S. Wales 2011, 137, 1-39. [CrossRef]

48. Zhao, H.; Zhang, S.; Zhu, M.; Ding, J.; Li, H.; Yang, T.; Wu, H. Paleomagnetic Insights into the Cambrian Biogeographic Conundrum: Did the North China Craton Link Laurentia and East Gondwana? Geology 2021, 49, 372-376. [CrossRef] 
49. Pang, K.; Wu, C.; Sun, Y.; Ouyang, Q.; Yuan, X.; Shen, B.; Lang, X.; Wang, R.; Chen, Z.; Zhou, C. New Ediacara-Type Fossils and Late Ediacaran Stratigraphy from the Northern Qaidam Basin (China): Paleogeographic Implications. Geology 2021, XX, 1-5. [CrossRef]

50. McKenzie, N.R.; Hughes, N.C.; Myrow, P.M.; Choi, D.K.; Park, T.Y. Trilobites and Zircons Link North China with the Eastern Himalaya during the Cambrian. Geology 2011, 39, 591-594. [CrossRef]

51. Han, Y.; Zhao, G.; Cawood, P.A.; Sun, M.; Eizenhöfer, P.R.; Hou, W.; Zhang, X.; Liu, Q. Tarim and North China Cratons Linked to Northern Gondwana through Switching Accretionary Tectonics and Collisional Orogenesis. Geology 2016, 44, 95-98. [CrossRef]

52. Zhang, Z.; Zhang, Z.; Popov, L.E.; Holmer, L.E. Earliest Ontogeny of Early Cambrian Acrotretoid Brachiopods-First Evidence for Metamorphosis and Its Implications. BMC Evol. Biol. 2018, 18. [CrossRef] [PubMed]

53. Laurie, J.R. Paterinide Musculature and Vascular Systems.Pdf. BMR J. Aust. Geol. Geophy. 1987, 10, $261-265$.

54. Babcock, L.E.; Robison, R.A.; Rees, M.N.; Peng, S.; Saltzman, M.R. The Global Boundary Stratotype Section and Point (GSSP) of the Drumian Stage (Cambrian) in the Drum Mountains, Utah, USA. Episodes 2007, 30, 85-95. [CrossRef]

55. Popov, L.E.; Bassett, M.G.; Zhemchuzhnikov, V.G.; Holmer, L.E.; Klishevich, I.A. Gondwanan Faunal Signatures from Early Palaeozoic Terranes of Kazakhstan and Central Asia: Evidence and Tectonic Implications. Geo. Soc. Lond. Spec. Pub. 2009, 325 23-64. [CrossRef]

56. Betts, M.J.; Paterson, J.R.; Jago, J.B.; Jacquet, S.M.; Skovsted, C.B.; Topper, T.P.; Brock, G.A. A New Lower Cambrian Shelly Fossil Biostratigraphy for Australia. Gondwana Res. 2016, 36, 176-208. [CrossRef]

57. Bassett-Butt, L. Systematics, Biostratigraphy and Biogeography of Brachiopods and Other Fossils from the Middle Cambrian Nelson Limestone, Antarctica. GFF 2016, 138, 377-392. [CrossRef]

58. Ushatinskaya, G.T. Protegulum and Brephic Shell of the Earliest Organophosphatic Brachiopods. Paleontol. J. 2016, 50, 37-47. [CrossRef]

59. Williams, A.; Popov, L.E.; Holmer, L.E.; Cusack, M. The Diversity and Phylogeny of the Paterinate Brachiopods. Paleontology 1998, 41, 221-262.

60. Popov, L.E.; Holmer, L.E.; Hughes, N.C.; Ghobadi Pour, M.; Myrow, P.M. Himalayan Cambrian Brachiopods. Pap. Palaeontol. 2015, 1, 345-399. [CrossRef]

61. Wang, Y.; Jin, Y.; Fan, D. Brachiopod Fossils of China; Science Press: Beijing, China, 1964; ISBN 1261000043520. (In Chinese)

62. Nemliher, J. A New Type of Shell Structure in a Phosphatic Brachiopod from the Cambrian of Estonia. Proc. Est. Acad. Sci. Geol. 2006, 55, 259-268.

63. Skovsted, C.B.; Holmer, L.E. The Early Cambrian (Botomian) Stem Group Brachiopod Mickwitzia from Northeast Greenland. Acta Palaeontol. Pol. 2003, 48, 1-20.

64. Lochman, C. Fauna of the Basal Bonneterre Dolomite (Upper Cambrian) of Southeastern Missouri. J. Paleontol. 1940, 14, 1-53.

65. Percival, I.G.; Kruse, P.D. Middle Cambrian Brachiopods from the Southern Georgina Basin of Central Australia. Mem. Assoc. Australas. Palaeontol. 2014, 1, 349-402.

66. Kruse, P. Cambrian Fauna of the Top Springs Limestone, Georgina Basin. Beagle Rec. Mus. Art Galleries North. Territ. 1991, 8 , 169-188. [CrossRef]

67. Holmer, L.; Popov, L.; Wrona, R. Early Cambrian Lingulate Brachiopods from Glacial Erratics of King George Island (South Shetland Islands), Antarctica. Acta Palaeontol. Pol. 1996, 55, 37-50.

68. Li, G.; Holmer, L.E. Early Cambrian Lingulate Brachiopods from the Shaanxi Province, China. GFF 2004, 126, 193-211. [CrossRef]

69. Balthasar, U. The Brachiopod Eoobolus from the Early Cambrian Mural Formation (Canadian Rocky Mountains). Paläontologische Zeitschrift 2009, 83, 407-418. [CrossRef]

70. Ushatinskaya, G.T.; Korovnikov, I.V. Revision of the Early-Middle Cambrian Lingulida (Brachiopoda) from the Siberian Platform. Paleontol. J. 2014, 48, 26-40. [CrossRef]

71. Streng, M.; Holmer, L.E.; Popov, L.E.; Budd, G.E. Columnar Shell Structures in Early Linguloid Brachiopods-New Data from the Middle Cambrian of Sweden. Earth Environ. Sci. Trans. R. Soc. Edinb. 2007, 98, 221-232. [CrossRef]

72. Griesshaber, E.; Schmahl, W.W.; Neuser, R.; Pettke, T.; Blüm, M.; Mutterlose, J.; Brand, U. Crystallographic Texture and Microstructure of Terebratulide Brachiopod Shell Calcite: An Optimized Materials Design with Hierarchical Architecture. Am. Mineral. 2007, 92, 722-734. [CrossRef]

73. Zhang, Z.; Zhang, Z.; Holmer, L.E. Studies on the shell ultrastructure and ontogeny of the oldest Acrotretid Brachiopods from South China. Acta Palaeontol. Sin. 2017, 56, 483-503, (In Chinese with English abstract). [CrossRef]

74. Pérez-Huerta, A.; Cusack, M.; McDonald, S.; Marone, F.; Stampanoni, M.; MacKay, S. Brachiopod Punctae: A Complexity in Shell Biomineralisation. J. Struct. Biol. 2009, 167, 62-67. [CrossRef]

75. Betts, M.J.; Claybourn, T.M.; Brock, G.A.; Jago, J.B.; Skovsted, C.B.; Paterson, J.R. Shelly Fossils from the Lower Cambrian White Point Conglomerate, Kangaroo Island, Australia. Acta Palaeontol. Pol. 2019, 64, 489-522. [CrossRef]

76. Poulsen, V. Notes on an Ordovician Acrotretacean Brachiopod from the Oslo Region. Bull. Geol. Soc. Den. 1971, 20, 265-278.

77. Liu, Y.J.; Peng, J.; Zhao, Y.L.; Mao, Y.Q. First Report of Schizopholis (Lingulata, Brachiopoda) from the Tsinghsutung Formation (Cambrian Series 2, Stage 4) in Guizhou, China. Palaeoworld 2021, 30, 422-429. [CrossRef]

78. Claybourn, T.M.; Skovsted, C.B.; Holmer, L.E.; Pan, B.; Myrow, P.M.; Topper, T.P.; Brock, G.A. Brachiopods from the Byrd Group (Cambrian Series 2, Stage 4) Central Transantarctic Mountains, East Antarctica: Biostratigraphy, Phylogeny and Systematics. Pap. Palaeontol. 2020, 6, 349-383. [CrossRef] 
79. Gubanov, A.P.; Peel, J.S. Oelandiella, the Earliest Cambrian Helcionelloid Mollusc from Siberia. Palaeontology 1999, 42, $211-222$. [CrossRef]

80. Skovsted, C.B.; Peel, J.S. Hyolithellus in Life Position from the Lower Cambrian of North Greenland. J. Paleontol. 2011, 85, 37-47. [CrossRef]

81. Skovsted, C.B.; Balthasar, U.; Vinther, J.; Sperling, E.A. Small Shelly Fossils and carbon isotopes from the Early Cambrian (Stages 3-4) Mural Formation of Western Laurentia. Pap. Palaeontol. 2021, 7, 951-983. [CrossRef] 